\section{Abstract}

\title{
Role of sediment in speleogenesis; sedimentation and paragenesis.
}

\author{
Andrew R Farrant ${ }^{\mathrm{a}^{*}}$ and Peter L Smart ${ }^{\mathrm{b}}$ \\ ${ }^{a}$ British Geological Survey, Keyworth, Nottingham, NG12 5GG, UK. arf@bgs.ac.uk \\ ${ }^{b}$ Department of Geographical Sciences, University of Bristol, Bristol, BS8 1SS, UK \\ *corresponding author
}

Although the effects of sedimentation in caves have been recognised for many years, its role in speleogenesis is frequently overlooked. Influxes of sediment into a cave system fundamentally alters the way cave passages develop, either by alluviation in a vadose environment, forcing lateral corrosion and the development of notches, or upwards dissolution in a phreatic environment through a process known as paragenesis. Sediment influxes affect the hydrological functioning of a karst aquifer by changing the way conduits behave and subsequently develop both in plan and long section.

Here we give an overview of the mechanisms of cave sedimentation and describe how the process of alluviation and paragenesis affect speleogenesis. A characteristic suite of meso- and micro-scale dissolutional features can be used to recognise paragenetic development, which is reviewed here. In a vadose environment these include alluvial notches, whilst in a phreatic environment, half tubes, anastomoses and pendants, bedrock fins and paragenetic dissolution ramps result. Using these to identify phases of sedimentation and paragenesis is crucial for reconstructing denudation chronologies from cave deposits. We suggest that sedimentation and paragenesis is most likely to occur in certain geomorphological situations, such as ice marginal and periglacial environments, beneath thick residual soils and where rivers can transport fluvial sediment into a cave, either via stream sinks or back-flooding.

Keywords: Paragenesis; Alluviation; Speleogenesis; Cave sedimentation; Karst landscape evolution.

\section{Introduction}

Caves are inherent sediment traps, and have yielded valuable paleoenvironmental and geomorphological information (Richards and Dorale, 2003; Sasowsky, 2007), but the role of sediment in speleogenesis, via a process known as paragenesis, although widely recognised, is generally underestimated. Paragenesis in a speleogenetic context (Renault, 1968; Lauritzen and Lundberg, 2000 ) is the process whereby sediment accumulation in a phreatic conduit forces dissolution on a restricted portion of the conduit perimeter, thus forcing speleogenesis in a certain direction, usually upwards. In this situation, sediment transport, deposition and dissolution are essentially coeval. A similar related process occurs where sedimentation takes place subsequent to passage formation, causing the burial of a cave passage and secondary modification of the passage walls. In a vadose environment, sediment input and dissolution may cause lateral incision, creating notches. All these processes give rise to a characteristic suite of passage morphologies, which are described herein. 
The concept of paragenesis has been known since the pioneering work of Renault in the 1960's. It has also been termed erosione antigravitativa by Pasini (1967; 1975), although Pasini (2009) suggests that the attribute antigravitative should be preferred to the attribute antigravitational. Many authors have recognised that paragenesis occurs and in some cases have provided specific examples (Despain and Stock, 2005; Farrant, 2004; Ford, 2000a; Ford and Ewers, 1978; Frumkin, 1998; Lauritzen and Lauritsen, 1995; Lundberg, 2005; Palmer, 2007; Simms and Hunt, 2008; Strasser et al., 2009; Šušteršič, 2006; Veni, 2005); however, despite this recognition, there is no comprehensive overview of the processes, nor of the morphology associated with both vadose sedimentation and phreatic paragenetic conduit development within the context of modern theories of speleogenesis.

Large influxes of sediment have a major effect on conduit development, infilling caves and forcing lateral corrosion and the development of notches in a vadose environment, or leading to upwards erosion in a phreatic environment. Sediment influxes also facilitate the development of floodwater mazes, thus fundamentally changing the type and style of conduit formed. Net rates of cavern enlargement can be much increased due to the effects of abrasion, especially when siliceous sediments are in transport (Newson, 1971). In this paper, we discuss the processes and environments of sedimentation within caves, its effect on speleogenesis both in vadose and phreatic environments, and explore the likely situations where paragenetic cave development or vadose sedimentation is to be expected.

Many caves display at least some often localised evidence of either sediment infilling and subsequent modification, or upwards erosion through paragenesis. This process is best observed in salt or gypsum caves where the greater solubility of the rock permits significant dissolution of passages walls and ceilings within timescales of sediment residence and human observation (Frumkin, 1998; Pasini, 2009). Recognising paragenetic phases in speleogenetic studies is important, as caves and cave sediments are often used to infer paleoclimatic changes (White, 2007) or rates of landscape evolution (Farrant et al., 1995; Granger et al., 2001; Stock et al., 2004). The development of cave passages where there is little or no sediment accumulation, have very different geomorphic and paleoclimatic implications compared to those modified by paragenetic processes. Thus identifying periods of sediment aggradation, paragenesis, and sediment flushing is necessary to fully interpret speleogenesis in response to base-level or climatic fluctuations. This requires a clear distinction between the primary upwards enlargement of passages in the epiphreatic or phreatic environment by paragenesis, and the secondary modification of an existing vadose passage following alluviation. Both processes may result in sediment-filled canyon passages, but the geomorphic and hydrological implications of these two possible origins are radically different (Figure 1). However, these processes can also be seen as two end members in a continuum, where ongoing sedimentation in a vadose passage can lead to fully phreatic conditions, causing paragenetic overprinting of vadose features and ultimately, continued upwards paragenesis within a wholly phreatic environment where sediment transport and 
accumulation is contemporaneous with dissolution and void development. Furthermore, the processes associated with alluviation and paragenesis, for example, the change from a free-flowing open conduit to partly occluded one, kept open only by sediment flushing under flood conditions, can affect the hydraulic dynamics of a conduit and thus the hydrological functioning of a karst aquifer. This can temporarily restrict conduit capacity and thus change local hydraulic gradients, particularly under high discharge conditions, alter flow patterns and reactivate relict conduits, thereby increasing the potential for groundwater flooding.

\section{[Figure 1 hereabouts]}

The true extent and significance of alluviation and paragenesis in speleogenesis is widely underestimated. This is partially because by their very nature, many paragenetic caves are flooded or choked with sediment, and thus remain unexplored. Moreover, even in explored caves, there is often no way of telling how much sediment is present; many passages have an unknown thickness of sediment beneath the floor, unless it has been excavated or removed by erosion. What can appear to be a small phreatic tube with a sediment floor may in fact be the top of a vertically extensive paragenetic gallery.

\section{Sediment sources and input mechanisms}

Two major sources of clastic cave sediments can be identified; autochthonous sedimentation derived from insoluble residues in the host bedrock, and allochthonous sediments derived from external sources, often via discrete inputs such as stream sinks and sinkholes. Autogenic sources are usually comparatively minor, but in impure carbonates or formations with significant amounts of secondary silica such as chert, considerable quantities of sediment may be generated. Allogenic sources of clastic sediment are normally derived from the erosion of adjacent or overlying clastic rocks and are transported predominantly by surface stream networks. These bring sediment directly into conduits via stream sinks. Additional factors, such as the mechanism of sediment input and nature of the sediment entrained, influence the style, type and flux of clastic sedimentation. The causes of sediment influx are varied and depend on the geomorphological, tectonic and climatic location of the cave.

Sediment can be entrained, trapped and flushed through a karstic conduit system in a variety of ways across a broad spectrum of geomorphological and climatic situations. Rates of sediment flux through conduits can vary enormously. In most regions, the rate and nature of sediment supplied is directly controlled by the climate which determines the weathering processes active at a given time (for example hill-slope process under interglacial versus periglacial conditions), the rate of weathering and thus the rate of sediment supply. Thus any change in climate automatically changes sediment influx; increases may lead to sediment accumulation and conversely decreases may lead to the flushing of existing sediments. Examples of climate-driven changes in sediment supply are documented in a semi-arid region by Auler et al., (2009) and in a tropical setting by Gillieson (1986). In glacial 
regions, the presence of ice over a karstic area may provide additional, temporary water and sediment inputs which are not present during interglacial times. This is particularly common in ice marginal settings and in alpine karst areas such as the Picos de Europa (Smart, 1986; Gisbert et al., 2000).

During periods of climatic change, existing and previously stable accumulations of sediment may be remobilised and transported underground. For example, significant quantities of weathered rock generated during an interglacial period may be mobilised as mass-movement events under a subsequent periglacial regime, particularly during summer melt-water seasons. Many of the clastic fills in caves in the United Kingdom, such as the chaotic breccias in Kent's Cavern in Devon (Proctor et al., 2005; Lundburg and McFarlane, 2007) were probably emplaced at the onset of climatic deterioration. Furthermore, anthropogenic changes in land-use can affect the rate of sediment flux. Use of caves to dispose of mining waste and runoff from agriculture and deforestation can increase sediment yields enormously (Ford and Williams, 2007), and will lead to the future development of paragenetic galleries. Ulrich (2002) provides a useful review of the impacts of human activities such as forestry and agriculture on temperate karst ecosystems.

Allochthonous clastic sediments can enter a conduit system in five main ways (Figure 2); via stream sinks (swallets), sinkhole collapse, via bedrock fissures and shaft drains, by glacial injection and through back-flooding from rivers. Conduit systems fed by allogenic stream sinks clearly represent a major focus of fluvial sedimentation. Depending on the catchment area, the source area for the sediment may be extensive and encompass a range of lithologies and environments and streams may provide a continuous or semi-continuous flux of sediment into a cave system. One recent study (Hart and Schurger, 2005) estimated the rate of sediment injection through stream-sinks to be $111 \mathrm{Mg} \mathrm{km}^{-2}$ year $^{-1}$ for a watershed in central Tennessee. Sinkhole formation and collapse also act as a significant sediment source. Some sinkholes may have developed synchronously with the cave, and thus acted as a sediment source throughout its lifetime, or they may develop as later, often random collapses, providing major, but episodic allochthonous sediment inputs.

\section{[Figure 2 hereabouts]}

Significant quantities of finer grained sediment may enter a cave system via bedrock fissures and shaft drains. White (2007) differentiated between soil wash-down, mainly soil from the epikarst that is washed into the cave through dissolutionally-widened fractures, and gravitational debris which is coarser-grained material that falls down open shafts. Bull (1981) suggested a translatory flow mechanism via fissures for the input of sub-glacial or glacial margin fine grained sediments into Agen Allwedd cave in South Wales, UK.

Direct glacial injection of sediment may plug open cave entrances with till, but more commonly, caves in ice marginal positions can act as subterranean glacial melt water channels (Ford et al., 1983; Kiernan et al., 2001), thereby acting in a similar manner to stream sinks, However, the location, size 
and duration of these melt water sinks may be radically different from interglacial sinks due to the presence of the ice. Some sediment may enter cave systems via resurgences through back-flooding from rivers. This is typically very minor or insignificant compared to the flux from upstream sources within the cave, but back-flooding is a very effective system for reducing sediment transport capability within the cave by reducing the head through the system and causing ponding. For some cave systems adjacent to rivers, this may lead to significant accumulations of finer grained sediment. Back-flooding assumes a greater significance where the river is actively aggrading its channel, for example due to glacial activity in its headwaters or climatic fluctuations. Aeolian sedimentation, principally sand and loess is comparatively rare, but may be locally important in certain arid environments, such as Saudi Arabia or parts of Australia (Darrénougué et al., 2009). More common is fluvial reworking of aeolian sediments into caves.

In some situations, such as glacial over-riding of a cave system, clastic sediments may be injected by more than one mechanism. Moreover, sediment influxes are not necessarily coeval with passage formation. Caves fed by allogenic drainage may receive a relatively constant supply of clastic debris, but some caves may be subject to alluviation long after they were formed, in some cases after they were abandoned by their formative streams. This is often the case with caves rejuvenated by sediment-laden glacial melt waters or caves that are affected by back-flooding following base-level rise.

\section{Sediments within caves}

By far the most common sedimentary facies within caves are clastic stream deposits. Bosch and White (2007) proposed a facies scheme for clastic cave sediments according to particle size and the degree of sorting (Figure 3). In channelized flow within caves, sediment transport is dominated by suspended load and bed-load. Channel facies typically occur as roughly stratified beds of sands, silts, and cobbles within and adjacent to stream channels, and can range in thickness from a few centimetres to tens of metres. Good sections through these deposits often occur where subsequent stream action has eroded through the fill, exposing the stratigraphy. Thalweg deposits are a derivative of the channel facies. These consist of coarse cobble grade sediments within the stream channel created by the winnowing out of finer grained material from channel deposits by stream action, and are thus generally coarser and better sorted.

\section{[Figure 3 hereabouts]}

A second distinctive derivative of channel deposits is the slack-water facies. These are the fine grained, often well laminated sediments that accumulate following flooding or ponding, and often cap clastic channel or thalweg deposits. Formed by the settling out of suspended sediment, especially adjacent to channels and within epi-phreatic or phreatic environments, these are perhaps the most 
widespread clastic deposits seen in caves. Good examples are the 'cap muds' seen in Agen Allwedd (Bull, 1981) and Clearwater Cave, Sarawak (Bull and Laverty, 1981).

Less common are diamicton facies. These are typically massive, very poorly sorted, chaotic sediments with little or no bedding. Generally, they consist of coarse gravels intermixed with variable amounts of sand, silt and clay that are deposited by debris flows, and are most common in high gradient cave passages and near entrances. Debris flows are normally triggered by extreme events, such as landslides, sinkhole collapse or floods. In glacial and periglacial regions, mass movements triggered by solifluction and sub-glacial melt water injection, can also form diamicton deposits, possibly under pipe-full 'sliding bed facies' (Saunderson, 1977). Examples of diamictons have been described from caves in New Guinea (Gillieson, 1986); they are also common in caves in the UK affected by periglacial processes such as Kent's Cavern, Devon (Proctor et al., 2005; Lundburg and McFarlane, 2007). True glacial diamictons, where ice has overridden caves and emplaced sediment within it are present in some cave systems, but are generally restricted to near-surface environments where ice can be forced into a passage. In some caves characterised by slow groundwater flow, such as network mazes and relict systems cut off from significant sediment supply, 'back-swamp' deposits may occur. These are generally fine grained, locally derived autochthonous sediments derived from dissolution of the host bedrock or soil derived material infiltrating through from the land-surface above.

The mean grain size of sediment influences deposition and entrainment. The coarse bed-load in many cave streams, in particular sand-rich facies, is easily transported into and through a cave system. Large pulses of sand and cobble grade sediment can be moved during flood events. Although much of the coarser material is sieved out through boulder chokes, disaggregated through transport, or retained in phreatic loops, the sand fraction is often transported through to the resurgence. In contrast, although readily transported, the finer silt and clay fractions are less easily entrained once deposited. Consequently, paragenesis is may be more common with fine grained sediment fills as they aren't readily re-entrained.

Thick sediment sequences tend to accumulate underground in several preferential situations (Figure 2). In stream channels, deposition is often caused by a rapid decrease in stream power and transport capacity. Thick sediment aggradations occur close to stream sinks, in phreatic loops and behind boulder chokes or other constrictions. Slack-water facies are common in relict passages that are subject to flooding. This is particularly the case in caves subject to base-level rise, such as some coastal regions or those affected by river back-flooding (Springer and Kite, 1997).

Depending on sediment supply and source, sediment accumulation may be highly localised, but in some systems, the whole cave may be affected. Similarly, neighbouring caves may have radically different morphologies depending on the degree of sediment input. Ford (1963) describes the contrast between Swildon's Hole and the sediment modified St Cuthbert's Swallet system in the Mendip Hills, 
211 UK. Sediment aggradation is normally temporally limited, related to episodic, one off or extreme 212 events such as landslide triggered debris flows, solifluction and periglacial mass-movements,

213 monsoon or cyclone-induced floods or sinkhole collapse. Under these circumstances, the resulting

214 deposits may not reflect the dominant hydrological conditions in the cave. As well as sediment

215 aggradation, sediment removal and flushing is a key process (for example, Despain and Stock, 2005;

216 Van Gundy and White, 2009). Evidence from the Friar's Hole system in Kentucky (Ford and

217 Williams, 2007, p. 319) suggests that over longer timescales the sediment flux through the cave is

218 normally much greater than the sediment stored within it. Both the gradual washing out of sediment

219 by normal stream-flows and drip-waters over extended periods of time, and catastrophic erosion by

220 floodwaters can remove significant quantities of accumulated sediment. Indeed, sediment infilling and

221 paragenetic cave development is commonly, but not always, a temporary phase in the cave-system

222 lifecycle. It is evident that the sediment storage function of caves and sinkholes varies both spatially

223 and temporally.

\section{4. Effects of sediment influx within caves}

225 Depending on the situation, the influx of sediment into a cave can result in a range of responses from

226 simple sediment-armouring of a vadose passage floor to the formation of fully developed paragenetic

227 passages within a phreatic environment. The initial stage in the development of a paragenetic passage

228 occurs when sediment accumulates within a passage. This can occur under normal conditions when

229 sediment input and transport are balanced, as the episodic nature of sediment transport means that

230 there may be extended periods of time when sediment masks the floor. However, it is more likely

231 when the rate of sediment input exceeds sediment transport through the system (Figure 4). This may

232 be in response to increased external sediment input, a reduction in stream power or accumulation

233 behind some form of blockage.

\subsection{Effects of sediment influx in a vadose setting}

235

236

237

238

239

In a vadose environment, sediment accumulation will lead to reduced vertical incision and increased lateral corrasion. At low discharge, sediment transport is limited and the sediment protects the bedrock floor from physical and chemical erosion, yet the stream retains its ability to chemically erode exposed bedrock, and incises horizontally into the wall where it flows against it. If the level of the sediment fill is stable, lateral incision will generate vadose alluvial notches coincident with the top of the fill. As meanders grow, their outer bends incise farther back into the walls, resulting in low, wide arcuate notches which may extend for tens to hundreds of metres down a passage, and in some cases kilometres (Farrant et al., 1995). Such vadose alluvial notches are invariably sub-horizontal, because their formation is linked directly to sediment accumulation below a free water surface (Figure $5 \mathrm{a}, \mathrm{b})$. They are generally much better developed than the shallow bedrock grooves incised by normal meandering vadose streams, and because they cut across the bedding and other geological structures, 
they can be readily distinguished from notches formed by differential erosion, particularly when taken in context with evidence of sediment fills. They are also distinct from waterline notches developed in standing water (Lauritzen and Lundberg, 2000) and marine coastal notches generated within the intertidal zone (Furlani et al., 2010) or around lake or swamp margins.

[Figure 4. hereabouts]

[Figure 5 (photos) hereabouts]

Vadose alluvial notches come in a range of sizes and forms, but are typically characterised by elliptical profiles. Their floors are often mantled with fluvial sediment, typically cobbles or pebbles. The sizes of notches are proportional to the amount and grain size of the sediment in transport, and thus indirectly, flood discharge. They often display well-developed scalloping indicating rapid vadose flow. Notches may also alternate from one side of the passage to another as the formative stream meandered across the sediment. This can lead to very complex passage cross sections with extensive undercuts and in some cases oxbows that may exceed $50 \mathrm{~m}$ in width. In some passages, several vertically stacked notches may be etched in the side of a single passage, marking successive positions of a sediment floor. Vadose alluvial notches thus reflect successive episodes of sediment aggradation, (which instigates notch development), and sediment flushing which permits trench incision (Figure 5a). The style of notch also depends on the nature of aggradation. If sediment aggradation is driven by resurgence-level ponding, as is the case in Clearwater Cave, Mulu (Smart et al., 1985), or internal ponding, then the resulting notch will be graded to the level of the spring or lake (Figure 5b). In caves where aggradation results solely from upstream sedimentation, for example via stream sinks, then the notches will be gently inclined corresponding with the stream gradient, but not tied to any particular base-level. This type of notch occurs in Charterhouse Cave in the Mendip Hills (Figure 5a) and in Ogof Draenen, South Wales, UK, where they can be traced for several hundred metres down a single passage (Waltham et al., 1997; Farrant and Simms, 2011). These notches decrease both in vertical size and lateral extent in a down-stream direction in tandem with a corresponding decrease in average sediment grain size. Once this diminishes to sand grade, sediment is easily entrained and is flushed through, and thus no longer accumulates to form notches. Most notches are a combination of the two, driven by both sediment input and graded to either an internal base-level (for example a boulder choke) or resurgence level.

Many other cave systems display vadose alluvial notches, especially low gradient river caves with allogenic catchments such as the Caves Branch system in Belize (Ford, 2000a). Perhaps the finest examples occur in the Mulu caves, Sarawak (Figure 5b). Here, notches relate to lateral incision

278 following sediment deposition controlled by external alluvial fan aggradation and base-level rise at 279 the resurgence (Farrant et al., 1995). They are up to $2 \mathrm{~m}$ high and $50 \mathrm{~m}$ wide, and can be traced for several kilometres through the system. Notches also occur in Amaterska Cave in the Czech Republic 
281 (Bruthans and Zeman, 2003); Crystal Cave, Sierra Nevada, California (Despain and Stock, 2005) and

282 Agen Allwedd, South Wales, UK (Simms and Hunt, 2008). Checkley (2010) provides a nice example

283 of a passage with multiple small scale notches, sediment banks and speleothem false floors from

284 County Pot, part of the Ease Gill Caverns system in Yorkshire, UK. In many other caves, local small-

285 scale notches may form above sediment accumulated behind boulder chokes or other constrictions. In

286 some vadose caves, rather than a distinct notch, a characteristic basal expansion of the passage cross

287 section may be displayed. This may be a precursor to a true notch, demonstrating a reduced rate of

288 vertical incision, rather than a distinct still-stand. However, basal lateral expansion may also be

289 caused by other factors such as discharge variations or changes in bedrock lithology so should be

290 interpreted with caution.

291 Sediment accumulation may continue until the entire passage is almost filled. If sufficient to restrict

292 flood discharges, aggradation will lead to increasingly epi-phreatic conditions, and continued

293 unchecked will eventually result in a fully paragenetic conduit where the passage evolves upwards

294 within a phreatic environment rather than laterally in the vadose zone. Full-scale paragenesis can be

295 viewed as the phreatic end product of continued alluviation in a vadose environment (Figure 1).

\section{4.2. Effects of sediment influx in a phreatic setting}

297 In contrast to the vadose situation, sediment accumulation in a phreatic environment will lead to the

298 vertical expansion of a passage by paragenesis. As a phreatic conduit enlarges through dissolution, so

299 the cross sectional area of the passage increases. Given the same discharge, the average flow velocity

300 thus decreases, reducing the sediment transport capacity of the conduit and favouring increased

301 sediment deposition on the passage floor. Thus average flow velocity is held constant at the threshold

302 of sediment transport. In this way a balance is maintained between sediment deposition,

303 transport and cross sectional area. Given stable or continued sediment influx the passage gradually

304 evolves upwards over time, as dissolution is concentrated on the walls and ceiling eventually creating

305 a high paragenetic gallery, terminating only at the local water table (Ford and Ewers, 1978). Under

306 these conditions, sediment transport and accumulation is contemporaneous with dissolution and void

307 development.

308 In addition to paragenesis, sediment influx prevents the continued down dip phreatic development of a 309 conduit by choking any incipient openings. This is clearly seen in the Armistice - Cairn Farm area of

310 Clearwater Cave, Sarawak (Figure 6). Here, the opportunities for capture of the Armistice Passage

311 conduit by new conduits developed along discontinuities within the underlying phreatic zone (phreatic

312 under-capture) are restricted or by sediment aggradation. This contrasts with the sediment free,

313 anastomotic bedding-plane morphology of the Cairn Farm conduit in the same part of the cave.

314 Sediment aggradation is thus an important factor in determining whether a predominantly phreatic or

315 a vadose system develops in response to base-level lowering. Given continued base-level lowering 
and a high sediment influx, the result is stacked tiers of notched vadose passages where otherwise a phreatic looping conduit would have developed. This means that the style of cave development as seen in Ogof Ffynnon Ddu, South Wales (Smart and Christopher, 1989), where phreatic loops are progressively eliminated by vadose incision, is inevitable where there is significant, periodic clastic input into a cave system.

\section{[Figure 6 hereabouts]}

\section{Characteristic dissolutional features}

Passages modified by sediment influx, either by infilling of an existing passage (alleviation) or paragenesis are often overlooked or mistaken for more archetypal phreatic and vadose development. This is partly because the characteristic features are often only visible once the sediment has been removed. Furthermore, paragenetic galleries developed by upwards erosion may superficially resemble vadose canyons. Distinguishing between the two is important because paragenetic galleries form below the water table whereas a vadose canyon is formed above it, but they are genetically and morphologically distinct. They have a characteristic suite of dissolutional features that enable them to be distinguished from vadose, epi-phreatic or wholly phreatic passages. Both paragenetic and alluviated passages usually have at least some extant remnants of a significant sediment fill (Figure 4d). This may range from an almost intact deposit that requires physical excavation to permit exploration, for example the Petites Dales cave developed in Cretaceous Chalk in Normandy, France (Rodet et al., 2006), to occasional remnant pockets of sediment preserved in alcoves or cemented by speleothem deposits.

\subsection{Paragenetic dissolutional features}

Paragenetic galleries can be distinguished from vadose passages by their phreatic wall morphology (scalloping, pendants, grooves). Moreover, although paragenetic galleries meander in a similar fashion to vadose canyons, the axis of meander migration propagates upwards in the direction of flow (Figure 7), as opposed to downwards in the case of vadose canyons (Ewers, 1985; Lauritzen and Lauritsen, 1995). This meander migration vector can be determined from canyon wall morphology and scallop-flow direction, and then plotted out on a stereonet (Pasini, 2009). However, this only works with small and relatively tightly meandering passages as meander wavelength is dependent on passage width. Vadose canyons often display a classic keyhole profile where the initial phreatic opening along a guiding bedding plane or fracture is at roof level. In paragenetic galleries this is not the case; the guiding fracture is at floor level, and upward erosion may lead to the development of an narrow slot, but there is often little difference in cross-sectional profile unless the discharge changes. Vadose trenches commonly display erosional potholes, both in the channel bed but also preserved as remnant alcoves in the walls that are abandoned as incision progresses, whereas paragenetic galleries do not. Vadose canyons also exhibit typical vadose wall morphologies, such as small rapid flow 
scallops, rills and vadose flutes. This is in marked contrast to the smooth rounded phreatic nature of paragenetic galleries. When breakdown and collapse occurs during paragenesis, the fallen blocks are encased in sediment and develop a characteristic rounded phreatic morphology. In some cases, where the passage wall has partially failed but remains supported by sediment, bedrock fins may develop, which can subsequently be exhumed. Good examples can be seen in some of the Mulu caves, Sarawak.

\section{[Figure 7 hereabouts]}

As well as the gross passage form, several dissolutional morphological features can be identified that indicate paragenetic development. These include: pendants and half tubes, 'drainage grooves' (cf Palmer, 2007), bedrock fins and paragenetic solution ramps (Figure 8). Where dissolution is concentrated against the roof or walls due to sediment aggradation, paragenetic half tubes (antigravitative ceiling channels of Pasini (2009)) may develop. These are channels with a semicircular or arched cross-section cut into the roof of a wider passage and developed where an almost complete sediment fill compels the formative stream to flow against the sediment-rock interface, carving one or more half tubes into the roof of a pre-existing passage. Ceiling meanders are an exaggerated form of half tube that develops upwards into narrow meandering paragenetic galleries incised into the roof of larger passages. Similarly, ceiling pendants are bedrock projections that result from the lateral development of half tubes, leaving isolated pendants between the channels. They are often well developed at ceiling level in paragenetic conduits, but can also develop beneath undercuts in alluviated vadose passages. Superb examples can be seen in Macumba Cave, Brazil; Mammoth Cave, Kentucky, and in Ogof Ffynnon Ddu (Figure 8c and 8d) and Ogof Draenen in South Wales, UK. Figure 5a shows examples developed on an undercut in an alluviated vadose passage in Charterhouse Cave, Mendip Hills, UK. In paragenetic passages, continued development of half tubes into bedrock walls may lead to the development of vertical rock fins projecting down into the passage. In extreme cases, particularly if fracture guided, half tubes may continue to develop upwards to create a suite of semi-parallel paragenetic rifts extending several metres above the original conduit, as seen in the Eldon Hill Quarry caves in Derbyshire, UK (Figure 9). Flow may also occur along the sides of the passage, so ceiling channels may migrate from the ceiling down the walls of the passage. Such half tubes are typically much smaller and more sinuous than the passage they occupy. This sinuosity can be caused by erosion and deposition of the sediment itself (Lauritzen and Lauritsen, 1995) as well as irregularities in the sediment-wall rock contact or the bedrock, but also because of the smaller discharge within these tubes. Not infrequently ceiling half-tubes have a marked flat sub-horizontal top, coincident with the local water-table. However, it should be stressed that although similar in morphology, these are distinct from the flat or concave solution ceilings generated by slowly convecting water bodies driven by solute density differences (Laugdecken) that are common in, but not exclusive to, evaporite caves (Kempe et al., 1975). They lack the characteristic vadose scalloping, 
and other paragenetic morphologies that are associated with alluvial notches, and often lack the evidence of an extant or former sediment fill.

\section{[Figure 8 (photos) hereabouts]}

Paragenetic dissolution ramps form in a similar manner to vadose alluvial notches, but in a phreatic environment at the level of the sediment floor (Figure 9). Preferential dissolution of the wall between a sediment fill and the ceiling will generate a notch, which will be subsequently abandoned as the ceiling continues to erode upwards. Because they form below the water-table, paragenetic solution ramps may be flat, inclined or undulating, reflecting the irregular sediment surface caused by variations in channel bed-load dynamics associated with undulations of the passage itself. These may be limited in extent, marking a single sediment bar, or may extend throughout a passage. Their sloping or undulating gradient and phreatic morphology distinguishes them from near horizontal vadose alluvial notches. Continued sedimentation in a phreatic environment will bury earlier paragenetic solution ramps beneath more sediment, with new notches formed at successively higher levels on the passage walls. Often, several inclined paragenetic solution ramps may occur, stacked one above the other, marking the migration of a sediment bank through an actively enlarging paragenetic passage. This is in contrast to vadose alluvial notches which become isolated from the stream by downward incision. In this way, phreatic solution ramps will remain concealed unless subsequent erosion of the sediment fill reveals them.

\section{[Figure 9 hereabouts]}

\subsection{Sub-alluvial dissolutional features.}

Wall-rock dissolution continues even when a passage becomes partially or completely filled with sediment. Vaughan et al., (1998) demonstrated that acidic water and dissolution occurs within the saturated sediment, although the total solute flux is much reduced. This generates a suite of dissolutional forms etched into the bedrock in addition to those described above, and these provide much of the morphological evidence for recognising former sediment fills. These typically small-scale dissolutional features are not restricted to fully phreatic paragenetic passages, but also form within sediment fills in alluviated vadose passages, especially on undercuts and below notches (for example see Figure 5a). Depending on the nature of the sediment fill, most water-flow and thus dissolution, is concentrated at the contact between the sediment and the rock wall or ceiling. This is particularly true in passages completely blocked by sediment, where high hydraulic heads across sediment blockages may force water along the more readily permeable sediment-rock interface. In addition, the sediment may compact under its own weight, particularly if fine grained, creating voids along the top and sides of the fill. If the passage dries out, then desiccation of the fill can give the same effect, providing routes for floodwater or later invasive streams. 
421 Once flow is established and confined into a series of channels, continued dissolution will result in the

422 development of smooth, sinuous, rounded, meandering half tubes incised into the bedrock walls.

423 These are typically a few centimetres across and may interconnect, forming a braided maze like

424 pattern etched into the overlying rock. They often form on the inclined underside of overhanging

425 walls that sometimes coalesce upwards into ceiling pendants. These have also been termed 'drainage

426 grooves' by Palmer (2007), who ascribed them to water draining down by gravity between the

427 sediment fill and bedrock following periodic floods. Although they mimic bedding plane anastomoses

428 if developed beneath bedding undercuts, they are morphologically and genetically different. Unlike

429 bedding plane anastomoses they are not confined to a single bedding plane or fracture and can occur

430 on vertical passage walls and ceilings, or commonly both (Figure $8 \mathrm{a}$ ). They frequently develop where

431 small inlets buried beneath the sediment fill feed water into a sediment-filled conduit.

\section{6. Effects on plan and long section geometry}

433 As described above, sedimentation and paragenesis not only modifies the internal passage

434 morphology, but can also modify long section geometry (Ford, 2000b) and cave patterns (Palmer,

435 2000). In caves with a phreatic looping profile, sediment accumulates in the base of phreatic loops

436 where paragenetic dissolution of the ceiling erodes the passage upwards. This process, combined with

437 vadose incision over loop crests, work together above and below the water-table to reduce passage

438 amplitude and create a water-table cave as the ultimate end product. The resulting passage often

439 contains alluvial notches. Figure 10 shows an example from Cobweb Cave in the Gunung Mulu

440 National Park, Sarawak. Ford (2000b) describes a classic example from Swildon's Hole in the Mendip

441 Hills, and similar examples can be seen in the nearby Charterhouse Cave.

\section{$442 \quad$ [Figure 10 hereabouts]}

443 Influxes of sediment can lead to the development of bypass passages or flood-water mazes, thus

444 altering the plan morphology of caves. These typically develop where sediment accumulation within a

445 phreatic loop or behind a boulder collapse leads to increased hydraulic head across the obstruction.

446 This enables the opening up of otherwise insignificant fissures, generating floodwater injection

447 features and creating a floodwater maze and/or bypass passages. These paragenetic floodwater mazes

448 typically have indistinct scalloping, paragenetic notches and pendants and often end in blind alcoves

449 or fissures. Two excellent examples can be observed in the Mynydd Llangattock cave systems in

450 South Wales, UK. In the Agen Allwedd cave system, the choked eastern end of the Main Passage

451 contains a sediment fill $>6 \mathrm{~m}$ thick and is characterised by a floodwater maze complex of blind rifts,

452 alcoves and paragenetic bypass passages (Figure 11). A similar situation occurs in the neighbouring

453 Ogof Craig yr Ffynnon where a major joint-guided conduit is punctuated by several massive boulder

454 chokes, some of which are directly beneath surface collapses on the moor $100 \mathrm{~m}$ above. Behind one of

455 these, over $20 \mathrm{~m}$ of sediment accumulated when the cave was still active. This has led to the 
development of a major sediment-filled paragenetic gallery upstream and a complex of blind side passages and avens with typical paragenetic wall morphologies that constitute a floodwater maze. Similar floodwater mazes have been described by Despain and Stock (2005) in the Catacombs section of Crystal Cave, California. This comprises a braided, curvilinear, anastomotic maze of now abandoned fossil passages formed on several sub-levels. They suggest that maze development is compounded in passages blocked or constricted by breakdown, secondary mineral deposits, or sediment fill. Similar examples are documented in the Sloans Valley cave system and Wells Cave, Kentucky (Simpson and Florea, 2009). Where a cave stream outlet has been buried by sediments, for example by fluvial aggradation of a river, a distributary system of fissures or tubes sometimes develop, bypassing the blockage and feeding overflow springs (Palmer, 1991).

\section{[Figure 11 hereabouts]}

\section{Examples of paragenetic caves}

Paragenetic caves are most likely to develop where sediment input is greatest. Consequently there are several settings where they tend to occur more often.

\subsection{Contact karst settings (sediment input via stream sinks).}

Most sediment enters cave systems via stream sinks. Thus large, low gradient river caves, particularly in tropical areas are often subject to paragenetic development. In these cases, sediment influx may be semi-continuous, with paragenesis occurring throughout the cave's development. Good examples occur in many tropical and lowland karst areas; for example the Gunung Mulu National Park in northern Sarawak (Smart et al., 1985). This area contains many extensive caves including the Clearwater-Blackrock-Whiterock and Terikan River systems. These are fed by major allogenic rivers draining adjacent sandstone mountains which have developed large alluvial fans where they debouch onto the adjacent lowlands. Fan aggradation is linked to increased rainfall during interglacials (Rose, 1984). Under these conditions coarse gravel is transported through the cave system. The build up of the alluvial fans by continued aggradation eventually leads to the blocking or submergence of the resurgences and causes ponding within the cave systems leading to the deposition of widespread mud (Bull and Laverty, 1981). Throughout the cave system, the cycle of cave formation, gravel accumulation followed by ponding and the deposition of the finer grained laminated silts has been repeated time and time again in response to climatic forcing (Farrant et al., 1995). This had led to sequential phases of notch formation (Figure $5 b$ ) and paragenetic cave development interspersed with base-level fall and vadose erosion. Similar examples occur in the Caves Branch system in Belize. The Caves Branch River, with a non-carbonate catchment area of $64 \mathrm{~km}^{2}$, sinks underground after flowing $10 \mathrm{~km}$ through an alluviated polje floored with clay, sand and cobbles derived from the adjacent highlands (Miller, 2006). This allogenic drainage has introduced copious amounts of coarse sediment into a low gradient conduit, causing vadose alluviation and notch formation (Ford, 2000a). Gillieson 
491 (1986) describes mechanisms of allogenic sediment input into Selminum Tem, Atea Kananda and

492 Bem Tem caves in Papua New Guinea. In both caves, he describes extensive sediment fills, together

493 with sponge-work mazes with dissolutional rock pendants indicative of paragenetic development. In

494 more temperate settings, allogenic drainage can also lead to significant alluviation and paragenetic

495 development. Good examples include Corkscrew Cave, Virginia where abundant sandstone has been

496 washed in from adjacent ridges (Palmer and Palmer, 2009 p. 45), parts of Mystery Cave, Minnesota

497 (Palmer and Palmer, 1995), and the Baradla-Dominica and Beke Cave systems straddling the

498 Hungary-Slovakia border (Bosák et al., 2004; Ford, 2000a).

499 7.2. Back-flooding and base-level rise.

500 Caves adjacent to base-level rivers or areas undergoing base-level rise are also prone to alluviation

501 and paragenetic development. Many river systems alternately aggrade and incise their channels

502 depending on sediment flux and changes in their base-level, raising and lowering the local water in

503 adjacent cave systems. These cycles are influenced by tectonics, but mostly driven by changes in

504 climate. The lower levels of Mammoth Cave, Kentucky provide some of the best current examples of

505 sediment aggradation due to back-flooding from adjacent rivers. In this case, the Green River has

506 aggraded its bed, leading to base-level rise. Considerable quantities of fine grained sediment can be

507 deposited within the lowest cave levels during the river flood stage. Relict passages in the upper levels

508 of Mammoth Cave and adjacent systems also contain extensive sediment fills, locally up to $20 \mathrm{~m}$

509 thick. These have been attributed to periodic sediment aggradation in surface valleys, probably caused

510 by climatic fluctuations. Cosmogenic isotope dating suggests that the upper levels of the cave formed

511 during a period of slow river incision and were later filled with sediment following a more

512 widespread rise in base level of up to $30 \mathrm{~m}$ around 2.6 Ma that may have coincided with the first

513 major North American glaciation (Granger et al., 2001). Similar sediment filled caves occur in

514 northern and eastern Kentucky, and Indiana (Wyandotte Cave, Palmer and Palmer, 2009 p. 127).

515 Paragenesis due to aggradation following base-level rise has also been documented in the Ardeche

516 River valley in southern France (Mocochain et al., 2009). This river underwent major aggradation in

517 the Late Pliocene, infilling canyons cut during the low stand of the Messinian salinity crisis. Springer

518 et al., (1997) describe examples of paragenetic maze caves created by back-flooding from the Cheat

519 River, West Virginia, including an example of a 4 m-wide elliptical tube plugged with laminated sand

520 and silt-clay rhythmites. The tube displays paragenetic pendants, bedrock fins and anastomosing half-

521 tubes on the passage ceiling. Frumkin (1998) cites base-level rise as a possible cause of alluviation

522 and paragenesis in a salt cave adjacent to the Dead Sea, Israel.

\section{$523 \quad$ 7.3. Glacial margin and fluvioglacial and periglacial settings}

524 Glacial melt water streams transport huge amounts of sediment, both as suspended load and bed load

525 (Gurnell, 1987). Thus caves located at or close to ice margins at some point during their history are 
likely to have experienced periods of high sediment input, particularly during deglaciation. As glacial activity is not necessarily coeval with cave formation, the peak sediment influx may have occurred some considerable time after the caves initially developed. Under these circumstances, the effect of sediment influx is initially to create a paragenetic overprint on existing passages, reactivating previously abandoned conduits and in some cases, developing new ones. This can generate a very complex genetic morphology. Lauritzen (1982) describes evidence of paragenesis in a sub-glacial environment from Pikhåggrottene, Svartisen, North Norway. Paragenetic development most likely occurred subglacially, but a second episode of coarse sediment emplacement occurred during a high discharge regime associated with deglaciation. Evidence of paragenesis is widespread in many caves of the Eastern Alps. Plan (2010) cites several examples including the Dachstein-Mammuthöhle system and the spectacular Paläeotraun of the Eisriesenwelt. Many of the high level phreatic passages within the caves of the Totes Gebirge (Burgunderschacht and DÖF-Sonnenleiter cave systems) are infilled with fine-grained sediments (Plan et al., 2009). These were emplaced during Pleistocene glaciations when the Totes Gebirge plateau was covered by Alpine ice streams. Back-flooding beneath these glaciers caused alluviation and paragenesis within the caves, causing the development of ceiling half tubes, ceiling meanders, and paragenetic bypass passages. Subsequent vadose rejuvenation during the present interglacial has locally intersected these old phreatic galleries and partly removed the sediment fill.

544 Williams (1996) provides an example of caves acting as glaciofluvial sediment traps in New Zealand.

545 The outlet to Aurora Cave was blocked by ice during glacial periods, thus trapping glaciofluvial 546 debris from adjacent valley glaciers within the cave. Some of the highest level passages are still 547 entirely choked, indicating that when the cave was overwhelmed by ice it completely filled with melt 548 water sediments, leading to paragenetic overprinting and cave development. During lesser glacial 549 advances, only the lower passages were flooded and subterranean aggradation surfaces developed up 550 to the maximum elevation of the sub-glacial water-table in the cave.

551 In the UK, many caves along the northern crop of the South Wales coalfield have been affected by 552 extensive glaciofluvial sediment input derived from adjacent former ice-sheets. Large quantities of 553 fine sand and silt from adjacent Devonian sandstone outcrops have been washed into the caves by 554 glacial or periglacial melt waters. In the Mynydd Llangattock cave systems, extensive sediment fills 555 are preserved, especially in the northern parts of Agen Allwedd (Bull, 1981) where Simms and Hunt 556 (2008) provide evidence of sediment influx, glacial flooding and impoundment. Smart and Gardner 557 (1988) indicate that these allochthonous sediments overlie a whole range of breakdown forms and thus postdate the main formation of the cave systems. Locally, paragenetic floodwater mazes have 559 developed behind boulder chokes. In Ogof Draenen, a few kilometres to the southeast, evidence from 560 sediment fills perched high on passage walls indicate that much of the lower part of the cave system 561 was ponded or filled with sediment. Moreover, cross bedding within these sediments indicate that 
when they were emplaced, hydraulic gradients were locally reversed to that of the formative stream. The evidence suggests the cave acted as a subterranean sub-glacial spillway, with sediment laden melt water overflowing out of former influent tributaries into an adjacent valley.

Elsewhere in the UK and northern Europe, most evidence of paragenesis is found in caves slightly beyond the last Devensian (Weichselian) or Anglian (Elsterian) glacial limit, but still subject to severe periglacial activity, particularly where local sources of allochthonous sediment occur. In the Peak District karst, good examples can be seen in Eldon Hill Quarry near Castleton, Derbyshire (Figure 9). Here, several narrow sinuous, sediment-filled canyon passages up to $15 \mathrm{~m}$ deep and $4 \mathrm{~m}$ wide were intersected by quarrying. The phreatic canyon-like passages with a lack of any obvious vadose features and the presence of well developed pendants, parasitic wall tubes, bedrock fins, grooves and paragenetic dissolution ramps throughout the height of the passage, coupled with the lack of bedding plane control and overwhelming evidence of a total sediment fill indicate the passages were formed under paragenetic conditions. These represent choked swallet caves infilled with coarse clastic sediments emplaced by summer melt water drainage and periglacial mass-movement off adjacent impermeable strata. Kent's Cavern, UK, mentioned earlier is another example of a cave with extensive sediment deposits emplaced under periglacial conditions.

\subsection{Caves beneath thick superficial deposits}

Another setting that can favour sedimentation and paragenetic development are cave systems developed beneath thick superficial deposits. Many caves in the Ozark Plateaus of Missouri are developed in limestones beneath a thick residual soil cover that is tens of metres thick in places. Caves in the region are well known for their abundant clay fill. Many of these sediments are reworked loessic soils and red brown residual clays derived from the local bedrock. Paragenetic features occur in some caves, for example Round Spring Cavern and Fisher Cave, which is also affected by backflooding (Scott House, 2009). In Brazil, the Lagoa Santa karst contains many caves with thick clastic sediment and evidence of paragenesis. Here, weathering of non-carbonate phyllite beds overlying the limestone has resulted in thick (as much as $50 \mathrm{~m}$ ) soil sequences covering much of the karst area (Auler et al., 2009). In the Cretaceous Chalk of the Anglo-Paris basin, especially in Normandy, most caves are infilled with silt and clay derived from overlying Palaeogene, Clay-with-Flints and loessic deposits (Rodet et al., 2006).

\section{Timescales of sedimentation and paragenesis}

Sediment aggradation and flushing is part of the normal life-cycle of a cave, and often occurs repeatedly over a range of timescales. Sediment fills are by their nature transitory and may be modified or even flushed out by a change in hydraulic regime. At any stage, sediment deposition and paragenetic development may be interrupted, terminated or reversed. At the shortest timescale, individual storms and mass-movement events can generate sediment fills that remain extant within the 
cave for days to decades. Observations by cave divers in the deep phreatic loops of Wookey Hole, Somerset, UK (Price, 2010) clearly demonstrate that the basal gravel is in a state of almost continual flux, and that the morphology of the sediment banks change with each passing flood. Over longer timescales $\left(10^{4}-10^{5}\right.$ years), sediment bodies may be generated as a result of climatic fluctuations, such as monsoonal variations or glacial cycles. At the other extreme, sediments in a deep phreatic looping system in a stable cratonic setting may remain in situ over $10^{5}-10^{6} \mathrm{yr}$ timescales before the conduit is abandoned. However, over the life cycle of a cave most sediment tends to be partially or totally removed by later vadose flows as an inevitable consequence of progressive base-level lowering. Sediment flushing by streams, inlets and drips can be a remarkably efficacious process. One or more cycles of phreatic or vadose development, sediment filling and paragenetic development, followed by partial or total sediment flushing are clearly recorded in some cave systems. Clearly, the ability to observe paragenetic features requires the sediment fill to be partially or totally removed, either by natural geomorphic processes or by human actions such as quarrying or excavation in the search for new passages. More rarely, where base-levels rise, caves may be buried and ultimately form relict palaeokarst.

\section{[Figure 12 hereabouts]}

\section{Conclusions}

Sediment accumulation in cave passages is a widespread, but poorly recognised phenomenon that affects speleogenesis. Sediment input, accumulation and flushing can be triggered by a range of factors, often as a result of climatic events. Within a cave, sediments can build up in certain situations, both within vadose and phreatic environments, leading to paragenetic (or antigravitative) erosion. This can be recognised in caves by a distinctive suite of dissolutional features that develop in fully or partially sediment filled passages. Partial sediment filling in a vadose environment leads to the development of dissolutional alluvial notches and paragenetic overprinting of existing vadose morphologies below the sediment fill level. Continued sedimentation may raise the water-table to create epi or fully phreatic conditions. In phreatic environments, sediment accumulation causes upwards dissolution and the development of paragenetic galleries. This process causes changes in both cave long section and plan geometry by infilling phreatic loops to create water-table caves and forcing the development of bypass passages, floodwater mazes and distributary spring networks. Moreover, paragenetic galleries are most likely to develop in certain geomorphological situations. Caves adjacent to sources of clastic sediment (such as allogenic drainage off clastic rocks, glacial outwash fans, aggrading rivers), beneath thick residual soils and in areas affected by base-level rise are most prone to sediment accumulation and paragenesis. Correctly identifying paragenetic phases is crucial when elucidating landscape denudation chronologies from cave deposits.

\section{Acknowledgements.}


632 We thank numerous cavers for logistical support underground, but particularly Mike Simms, Clive

633 Gardner, Alison Moody and members of the Mulu Caves Project, especially Dick Willis and Fiona

634 Whitaker. Also thanks to cave photographers Peter Hann, Tony Waltham and Brendan Marris. Three

635 reviewers provided useful comments.

\section{References}

637 Auler, A.S. Smart, P.L., Wang, X., Pilo, L.B., Edwards, R.L., 2009. Cyclic sedimentation in Brazilian 638 caves: Mechanisms and palaeoenvironmental significance. Geomorphology 106, 142-153.

639 Bosák, P., Hercman, H., Kadlec, J., Móga, J., Pruner, P., 2004. Palaeomagnetic and U-series dating of 640 cave sediments in Baradla Cave, Hungary. Acta Carsologica 33, 219-238

641 Bosch, R., White, W.B., 2007. Lithofacies and transport of clastic sediments in karstic aquifers. In:

642 Sasowsky, I.D., Mylroie, J., Bosch, R., White, W. (Eds.), Studies of Cave Sediments. Springer

643 Netherlands, pp. 1-22.

644 Bruthans, J, Zeman, O., 2003. Factors controlling exokarst morphology and sediment transport 645 through caves: comparison of carbonate and salt karst. Acta Carsologica 32, 83-99.

646 Bull, P.A., 1981. Some fine-grained sedimentation phenomena in caves. Earth Surface Processes and 647 Landforms 6, 11-22.

648 Bull, P.A., Laverty, M., 1981. Cave sediments. In: Eavis, A.J. (Ed.), Caves of Mulu '80. Royal 649 Geographical Society, London.

650 Checkley, D.C., 2010. A long and complex story from County Pot. Speleology 16, 6-7.

651 Darrenougue, N., De Deckker, P., Fitzsimmons, K., Norman, M., Reed, E.H., van der Kaars, S., 652 Fallon, S., 2009. A late Pleistocene record of aeolian sedimentation in Blanche Cave, Naracoorte, 653 South Australia. Quaternary Science Reviews 28, 2600-2615.

654 Despain, J.D., Stock, G.M., 2005. Geomorphic history of Crystal Cave, Southern Sierra Nevada, 655 California. Journal of Cave and Karst Studies 67, 92-102.

656 Ewers, R.O., 1985. Patterns of cave development along the Cumberland Escarpment. In: Dougherty, 657 P.H. (Ed.), Caves and karst of Kentucky. Kentucky Geological Survey Special Publication, pp. 63-77.

658 Farrant, A.R., 2004. Paragenesis. In: Gunn, J. (Ed.), Encyclopedia of Caves and Karst Science.

659 Fitzroy Dearborn, New York - London, pp. 569 - 571. 
660 Farrant, A.R., Smart, P.L., Whitaker, F.F., Tarling, D.H., 1995. Long-term Quaternary uplift rates

661 inferred from limestone caves in Sarawak, Malaysia. Geology 23, 357-360.

662 Farrant A.R., Simms, M.J., 2011. Ogof Draenen: speleogenesis of a hydrological see-saw from the 663 karst of South Wales. Cave and Karst Science 38, 31-52

664 Ford, D.C., 1963. Aspects of the geomorphology of the Mendip Hills, Ph.D. Thesis. Oxford 665 University, Oxford.

666 Ford, D.C., 2000a. Caves Branch, Belize, and the Baradla-Dominica system, Hungary and Slovakia. 667 In: Klimchouk, A.B., Ford, D.C., Palmer, A.N., Dreybrodt, W., (Eds.), Speleogenesis: Evolution of 668 Karst Aquifers. National Speleological Society, Huntsville, Alabama, pp. 391-396.

669 Ford, D.C., 2000b. Speleogenesis under unconfined settings. In: Klimchouk, A.B., Ford, D.C., 670 Palmer, A.N., Dreybrodt, W. (Eds.), Speleogenesis: Evolution of Karst Aquifers. National 671 Speleological Society, Huntsville, Alabama, pp. 319-324.

672 Ford, D.C., Ewers, R.O., 1978. The development of limestone cave systems in the dimensions of 673 length and depth. Canadian Journal of Earth Science 15, 1783-1798.

674 Ford, D.C., Smart, P.L., Ewers, R.O., 1983. The physiography and speleogenesis of Castleguard 675 Cave, Columbia Icefields, Alberta, Canada. Arctic and Alpine Research 15, 437-450.

676 Ford, D.C., Williams, P., 2007. Karst Hydrogeology and Geomorphology. John Wiley and Sons, 677 Chichester, UK, $562 \mathrm{pp}$.

678 Frumkin, A., 1998. Salt cave cross-sections and their paleoenvironmental implications.

679 Geomorphology 23, 183-191.

680 Furlani, S., Cucchi, F., Biolchi, S., Odorico, R., 2010. Notches in the Northern Adriatic Sea: Genesis 681 and development. Quaternary International, In Press.

682 Gillieson, D., 1986. Cave sedimentation in the New Guinea highlands. Earth Surface Processes and 683 Landforms 11, 533-543.

684 Gisbert F., Rossi, C., Calaforra, J.M. 2000. Speleogenesis in the Picos de Europa Massif, Northern 685 Spain. In: Klimchouk, A.B., Ford, D.C., Palmer, A.N., Dreybrodt, W. (Eds.), Speleogenesis:

686 Evolution of Karst Aquifers. National Speleological Society, Huntsville, Alabama, pp. 352-357. 
687 Granger, D.E., Fabel, D., Palmer, A.N., 2001. Pliocene-Pleistocene incision of the Green River, 688 Kentucky, determined from radioactive decay of cosmogenic ${ }^{26} \mathrm{Al}$ and ${ }^{10} \mathrm{Be}$ in Mammoth Cave 689 sediments. Geological Society of America Bulletin 113, 825-836.

690 Gurnell, A.M., 1987. Suspended sediments. In: Gurnell, A.M., Clark, M.J. (Eds), Glacio-Fluvial 691 Sediment Transfer. An Alpine Perspective. John Wiley \& Sons Ltd, Chichester, UK, pp. 305-354.

692 Hart, E.A., Schurger, S., 2005. Sediment Storage and Yield in an Urbanized Karst Watershed.

693 Geomorphology 70, 85-96.

694 Kempe, S., Brandt, A., Seeger, M., Vladi, F., 1975. Facetten" and "Laugdecken", the typical 695 morphological elements of caves developing in standing water. Annales de Spéléologie 30, 705-708.

696 Kiernan, K., Lauritzen, S.E., Duhig, N., 2001. Glaciation and cave sediment aggradation around the 697 margins of the Mt Field Plateau, Tasmania. Australian Journal of Earth Sciences 48, 251-263.

698 Lauritzen, S.-E., 1982. The paleocurrents and morphology of Pikhaggrottene, Svartisen, North 699 Norway. Norsk Geografisk Tidsskrift 36, 183-209.

700 Lauritzen, S.-E., Lauritsen, A., 1995. Differential diagnosis of paragenetic and vadose canyons. Cave 701 and Karst Science 21, 55-59.

702 Lauritzen, S.E., Lundberg, J., 2000. Meso- and micromorphology of caves: Solutional and erosional morphology. In: Klimchouk, A.B., Ford, D.C., Palmer, A.N., Dreybrodt, W. (Eds.), Speleogenesis: Evolution of Karst Aquifers. National Speleological Society, Huntsville, Alabama, pp. 408-426. Academic Press, New York, pp. 315-321.

Lundberg, J., McFarlane, D.A., 2007. Pleistocene depositional history in a periglacial terrane: A 500ka record from Kent's Cavern, Devon, United Kingdom. Geosphere 3, 199-219.

Miller, T.E., 2006. Integration of a large tropical cave network in brecciated limestone: Caves Branch, Belize. Geological Society of America Special Papers 404, 91-103. karst landscape and caves: Example of the Lower Ardèche river (mid Rhône valley). Geomorphology $106,46-61$.

714 Newson, M.D., 1971. The role of abrasion in cavern development. Transactions of the Cave Research 715 Group of Great Britain 13, 101-107. 
716 Palmer, A.N., 1991. The origin and morphology of limestone caves. Geological Society of America

717 Bulletin 103, 1-21.

718 Palmer, A.N., 2000. Hydrogeologic control of cave patterns. In: Klimchouk, A.B., Ford, D.C.,

719 Palmer, A.N., Dreybrodt, W. (Eds.), Speleogenesis: Evolution of Karst Aquifers. National

720 Speleological Society, Huntsville, Alabama, pp. 77-90.

721 Palmer, A.N., 2007. Cave Geology. Cave Books, Dayton, Ohio, 454 pp.

722 Palmer, A.N., Palmer, M.V., 1995. Geology and origin of Mystery Cave, Forestville State Park,

723 Minnesota, Minnesota Department of Natural Resources, St Paul, Minnesota.

724 Palmer, A.N., Palmer, M.V., 2009. Caves and karst of the USA. National Speleological Society,

725 Huntsville, Alabama, 445 pp.

726 Pasini, G., 1967. Nota preliminare sul ruolo speleogenetico dell' erosione "antigravitativa". Le Grotte 727 d'Italia 4, 75-90.

Pasini, G., 1975. Sull'importanza speleogenetica dell' "erosione antigravitativa". Le Grotte d'Italia 4, 297-322.

730

Pasini, G., 2009. A terminological matter: paragenesis, antigravitative erosion or antigravitational erosion. International Journal of Speleology 38, 129-138.

732 Plan, L., 2010. Significance of paragenesis in caves of the Eastern Alps. Geophysical Research

733 Abstracts, 12, EGU2010-14673.

734 Plan, L., Filliponi, M., Behm, M., Seebacher, R., Jeutter, P., 2009. Constraints on alpine speleogenesis 735 from cave morphology - A case study from the eastern Totes Gebirge (Northern Calcareous Alps, 736 Austria). Geomorphology 106, 118-119.

737 Price, D., 2010. Full Circle. In: Hanwell, J.D., Price, D. and Witcombe, R. (Eds), Wookey Hole - 75

738 years of cave diving and exploration. Cave Diving Group, Wells, pp. 346.

739 Proctor, C.J., Berridge, P.J., Bishop, M.J., Richards, D.A., Smart, P.L., 2005. Age of Middle 740 Pleistocene fauna and Lower Palaeolithic industries from Kent's Cavern, Devon. Quaternary Science 741 Reviews 24, 1243-1252.

742 Renault, P., 1968. Contribution à l'etude des actions mécaniques et sédimentologiques dans la 743 spéleogenèse. Annales de Spéléologie 23, 529-596. 
744 Richards, D.A., Dorale, J.A., 2003. U-series chronology of speleothems and paleoclimate. Uranium-

745 Series Geochemistry. Reviews in Mineralogy and Geochemistry 52, 407-460.

746 Rodet, J., Laignel, B., Brocard, G., Dupuis, E., Massei, N., Viard, J-P., 2006. Contribution of a

747 sedimentary study to the concept of karstic evolution of a chalk cave in the western Paris Basin

748 (Normandy, France). Geologica Belgica 9, 287-296.

749 Rose, J., 1984. Alluvial terraces of an equatorial river, Melinau drainage basin, Sarawak. Zeitschrift 750 fuer Geomorphologie 28, 155 - 177.

751 Sasowsky, I.D. (Ed.), 2007. Clastic sediments in caves. Imperfect recorders of processes in karst.

752 Time in Karst, 12. Karst Waters Institute Special Publication, 143-149 pp.

753 Saunderson, H.C., 1977. The sliding bed facies in esker sands and gravels: a criterion for full-pipe 754 (tunnel) flow? Sedimentology 24, 623-38.

755 Scott House, R., 2009. Significant features of the Missouri karst. In: Palmer, A.N., Palmer, M.V.

756 (Eds), Caves and karst of the USA. National Speleological Society, Huntsville, Alabama, pp. 162757170.

758 Simms, M.J., Hunt, J.B., 2008. Flow capture and reversal in the Agen Allwedd Entrance Series, South

759 Wales: evidence for glacial flooding and impoundment. Cave and Karst Science 34, 69-76.

760 Simpson, L.C., Florea, L.J., 2009. The Cumberland Plateau of Eastern Kentucky. In: Palmer, A.N.,

761 Palmer, M.V. (Eds), Caves and karst of the USA. National Speleological Society, Huntsville,

762 Alabama, pp. 70-78.

763 Smart, P.L., 1986. Origin and development of glacio-karst closed depressions in the Picos de Europa,

764 Spain. Zeitschrift für Geomorphologie 30, 423-443.

765 Smart, P.L., Bull, P.A., Ross J., Laverty, M., Noel, M., 1985. Surface and underground fluvial activity 766 in the Gunong Mulu National Park, Sarawak. In: Douglas, I., Spencer, T. (Eds), Environmental

767 change and tropical geomorphology. Allen and Unwin, London, pp. 123-148.

768 Smart, P.L., Christopher, N.S.J., 1989. Ogof Ffynnon Ddu. In: Ford, T.D. (Ed.), Limestones and

769 Caves of Wales. Cambridge University Press, Cambridge, pp. 177-189.

770 Smart, P.L., Gardner, C.G., 1988. The Mynydd Llangattock Cave Systems. In: Ford, T.D. (Ed.),

771 Limestones and caves of Wales. Cambridge University Press, Cambridge, pp. 124-151. 
Springer, G.S., Kite, J.S., 1997. River-derived slackwater sediments in caves along Cheat River, West Virginia. Geomorphology 18, 91-100.

Springer, G.S., Kite, J.S., Schmidt, V.A., 1997. Cave sedimentation, genesis, and erosional history in the Cheat River Canyon, West Virginia. Geological Society of America Bulletin 109, 524-532.

Stock, G.M., Anderson, R.S., Finkel, R.C., 2004. Pace of landscape evolution in the Sierra Nevada, California, revealed by cosmogenic dating of cave sediments. Geology 32, 193-196.

Strasser, M., Strasser, A., Pelz, K., Seyfried, H., 2009. A mid Miocene to early Pleistocene multi-level cave as a gauge for tectonic uplift of the Swabian Alb (Southwest Germany) Geomorphology 106, 130-141.

Šušteršič, F., 2006. Relationships between deflector faults, collapse dolines and collector channel formation: some examples from Slovenia. International Journal of Speleology 35, 1-12.

Urich, P.B., 2002. Land use in karst terrain: review of impacts of primary activities on temperate karst ecosystems. Science for Conservation 198, $60 \mathrm{pp}$.

Van Gundy, J.J., White, W.B., 2009. Sediment flushing in Mystic Cave, West Virginia, USA, in response to the 1985 Potomac Valley flood. International Journal of Speleology 38, 103-109.

Vaughan, K., Groves, C., Meiman, J., 1998. Carbonate chemistry of interstitial fluids within cave stream sediments, Proceedings of the International Geological Correlation Program, Project 379: Karst processes and the global carbon cycle. Proceedings of the International Meeting of the International Geological Correlation Program, Project 379, Bowling Green, Kentucky.

Veni, G., 2005. Passages. In: Culver, D.C., White, W.B. (Eds), Encyclopedia of Caves. Elsevier Academic Press, New York, pp. 436-440.

Waltham, A.C., Simms, M.J., Farrant, A.R., Goldie, H.S., 1997. Karst \& Caves of Great Britain. Geological Conservation Review, 12. Chapman and Hall, London.

White, W.B., 2007. Cave sediments and paleoclimate. Journal of Cave and Karst Studies 69, 76-93.

Williams, P.W., 1996. A 230 ka record of glacial and interglacial events from Aurora Cave, Fiordland, New Zealand. New Zealand Journal of Geology and Geophysics 39, 225-241. 


\section{Figure 1.}

803 Schematic evolution of a conduit showing the effect of sediment influx into both vadose and phreatic environments. In a phreatic environment (A), sedimentation will result in the upwards dissolution of a conduit by paragenesis, creating a sediment filled gallery whose top is coincident with the local watertable. In a vadose environment (B), the initial phreatic tube may be incised by one or more phases of vadose incision, creating a classic keyhole passage cross section (shown at $\mathrm{t}=2 \mathrm{a}-\mathrm{d}$ in the section). Subsequent alluviation by sediment may infill an existing vadose passage, leading to paragenetic-type overprinting of existing vadose morphologies. This may be associated with one or more phases of sedimentation and flushing. If sedimentation continues unchecked, it may eventually lead to full paragenesis in a phreatic environment, with the development of paragenetic rifts incised upwards into the roof of the existing phreatic tube. Each of the individual phreatic, vadose and paragenetic components at $\mathrm{t}=4$ may be formed at different times under different discharge regimes, and thus may not be equal in size.

Figure 2.

816 Schematic cross-section of a cave system showing major sediment influx routes and accumulation 817 points. Sediment entry points: A. via stream sinks. B. Through sinkhole collapse and surface runoff 818 via open sinkholes (collapse debris is shown as darker grey). C. Via fissure networks within the 819 epikarst, dissolution pipes and shaft drains. D. Back-flooding from adjacent river systems, both via 820 springs and relict passages during flood events, especially in areas with rising base-level. E. Glacial injection, either by direct sub-glacial injection of till or from glaciofluvial outwash.

822 Preferred areas of sediment accumulation: 1. Near surface passages close to sediment input points, 823 especially low gradient river passages or constricted entrance passages. 2. Behind boulder collapses, 824 or other restrictions such as sinkhole collapses. 3. Within phreatic loops, or in flooded sections of cave 825 passage with standing water. 4. In active and relict passages subject to back-flooding from rivers. 5. In relict passages subject to infilling from shaft drains and fissures.

\section{$827 \quad$ Figure 3.}

828 Figure 3. Schematic cartoon of a stream cave with relict tributary and network maze passages

829 showing the classification of clastic cave sediment facies outlined Bosch and White, 2007.

831 Evolution of paragenetic galleries and alluvial notches in phreatic and vadose situations (elevation and cross sections) under conditions of high sediment flux and following abandonment. 
834 Vadose alluvial notches.

835 5a) Coarse sandstone-rich sediment washed into this joint-guided vadose passage has formed two 836 notches visible on the walls, one just above head height of the caver in the foreground, the second at 837 chest height. A third vadose alluvial notch is currently developing at floor level, level with the coarse

838 sediment fill. Paragenetic anastomoses, pendants and half tubes have developed on the undercut 839 below the middle notch. Onion Passage, Route 66, Charterhouse Cave, Somerset, UK. Photo by Peter 840 Hann.

$8415 b$ ). Large scale vadose alluvial notch developed by fluvial aggradation in a humid tropical 842 environment, Clearwater Cave, Gunung Mulu, Sarawak. The notches developed during periods when 843 the Melinau River was routed through the cave during periods of active alluvial fan aggradation. The 844 present river is no longer fed by major allogenic sources and is therefore not currently aggrading its 845 bed. Photo by Tony Waltham Geophotos.

\section{$846 \quad$ Figure 6.}

847 Plan and cross sections through the Armistice and Cairn Farm passages in the upper part of 848 Clearwater Cave, Mulu, Sarawak. Armistice Passage has an allogenic sediment fill which has 849 prevented down-dip phreatic under-capture. In contrast, the Cairn Farm series of passages (which 850 underlies Armistice) does not have a significant fill and consequently has developed a phreatic 851 looping profile, giving rise to very different plan and long section passage geometry.

\section{$852 \quad$ Figure 7.}

853 Figure 7. Differential diagnosis between vadose canyons and paragenetic (antigravitative) canyons.

854 Vadose canyons form above the water-table whilst paragenetic canyons form below it, thus forming a 855 mirror pair. The meander migration vector (MMV) is determined from scalloping and canyon walls, 856 and can be plotted on the upper and lower hemispheres of a stereonet. Figure from Lauritzen and 857 Lauritsen, (1995).

\section{$858 \quad$ Figure 8. (photos)}

859 Photomontage of characteristic meso and micro dissolutional features associated with paragenesis.

860 8a. Anastomotic half tubes etched into the underside of an overhang following vadose alluviation, 861 Padlock Passage, Ogof Draenen, South Wales, UK. Photo by M J Simms.

862 8b. Paragenetic roof tube and vadose canyon. This passage, developed along a prominent joint, displays phreatic, paragenetic and vadose features. The uppermost part of the passage is a well 
developed rounded phreatic tube (developed above the sediment fill) beneath which is a narrower

865 paragenetic gallery, but with characteristic smooth rounded forms typical of a phreatic environment.

866 The sediment was subsequently flushed out and a vadose trench incised into the floor (below the

867 figure). Raider's Passage, Ogof Draenen, South Wales, UK. Photo by M J Simms.

868 8c. Paragenetic anastomoses, pendants and half tubes in a paragenetic passage. Columns Passage,

869 Ogof Ffynnon Ddu I, South Wales, UK. Photo by B. Marris.

$8708 \mathrm{~d}$. Anastomotic paragenetic half tubes on passage walls with intervening pendants in a phreatic

871 passage infilled by glacially derived sediment. Entrance Passage, Ogof Ffynnon Ddu II (Top

872 Entrance), South Wales, UK. Photo by B. Marris.

\section{$873 \quad$ Figure 9.}

874 Figure 9. Section through a paragenetic passage exposed by quarrying, Eldon Hill Quarry, Derbyshire,

875 UK. This is a longitudinal section, where one wall of a sediment filled passage has been removed by

876 quarrying allowing sight of the other wall. The former passage is marked by brown mud-stained

877 dissolutionally etched limestone. Above and to the left of the figure are several conspicuous

878 paragenetic dissolution ramps (a) dipping steeply down to the quarry floor on the left of the image.

879 The prominent bedding plane at head height has been picked out by dissolution and displays several

880 examples of paragenetic pendants (b). Remnants of the sediment fill form the scree slopes upon which

881 the figure (approximately $1.9 \mathrm{~m}$ tall) is standing. The passage exits the quarry through a small $1 \mathrm{~m}$

882 diameter tube to the left of the image. Photo by M J Simms. Similar paragenetic dissolution ramps are

883 shown in Palmer (2007), p. 154.

884 Figure 10.

885 Example of sequential paragenetic development and vadose notch formation from Cobweb Cave,

886 Gunung Mulu National Park, Sarawak. Notch development initially graded to a water-table at $120 \mathrm{~m}$

887 followed by a fall to $65 \mathrm{~m}$. Much of the sediment fill has been eroded by later vadose invasion stream

888 activity. Inset: Paragenetic influences on passage long section. Vadose incision over loop crests and

889 paragenetic upwards erosion in phreatic loops (A) combine to create a graded water-table cave (B).

$890 \quad$ Figure 11.

891 Plan view of the eastern end of the Main Passage in Agen Allwedd, Mynydd Llangattock, South

892 Wales, UK. Collapse has led to the development of a paragenetic flood-water maze around the

893 terminal choke (North Wing and Aven Series), and caused the development of a paragenetic bypass

894 passage developed along joints to the southeast (Trident Passage). 
896 Schematic life-cycle of a hypothetical cave over time. In this example, multiple phases of sediment

897 accumulation and flushing have occurred over a range of timescales in response to external forcing.

898 This may be due to short term events such as individual storms or mass movement events, or to longer

899 term climatic changes such as a change to a glacial or periglacial regime or fluctuations in monsoonal

900 rainfall. Initially, phreatic dissolution with coeval sediment aggradation led to upwards paragenesis.

901 Subsequent base level fall caused a period of vadose incision, only for a second phase of sediment

902 accumulation to bury the passage, overprinting existing vadose morphologies. Ultimately,

903 abandonment, often preceded by at least partial sediment flushing and vadose rejuvenation, is the

904 almost inevitable consequence of longer term uplift and or base-level fall. This is one of many

905 alternative scenarios. In some caves, the amount of sediment input and residence time may be

906 negligible, in others large amounts of sediment may reside in the cave for much of its lifespan. 


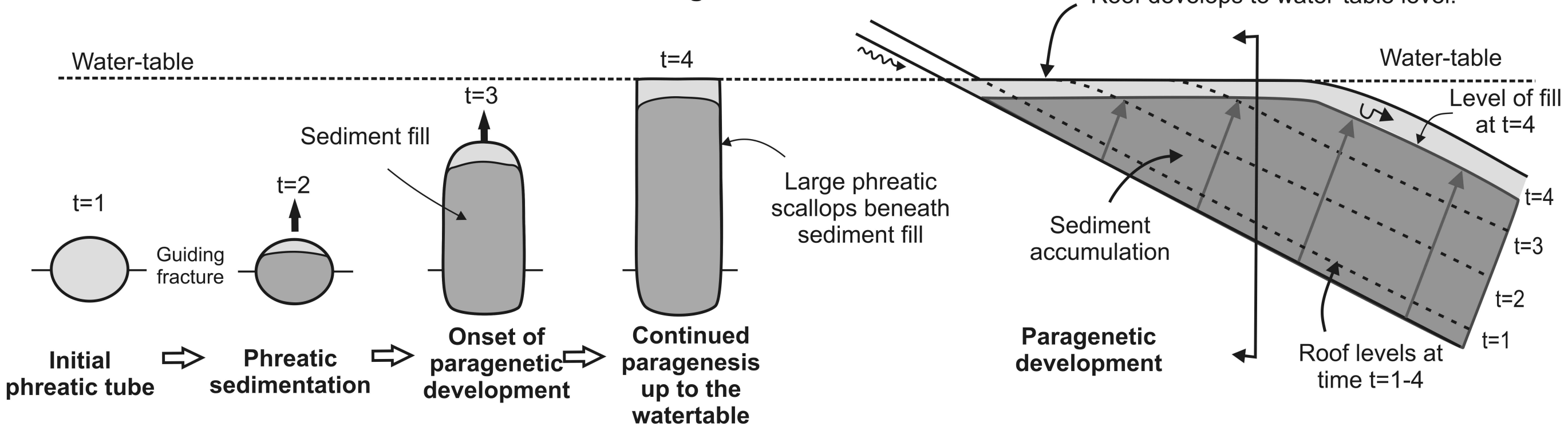

\section{B. Vadose Environment - Incision followed by alluviation}

\section{SECTION}


graded to water-table 


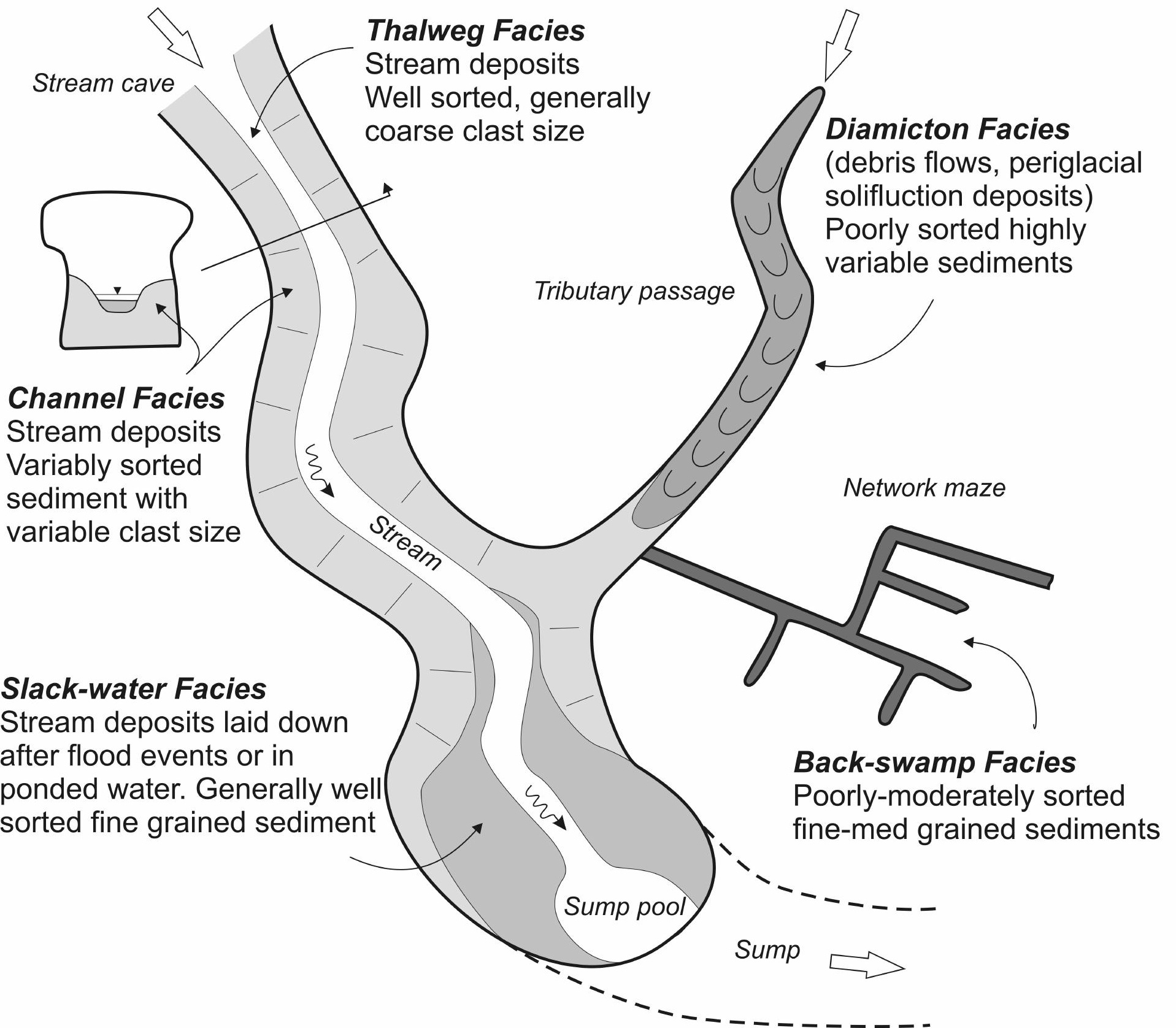




\section{$t=1$ Original phreatic loop}

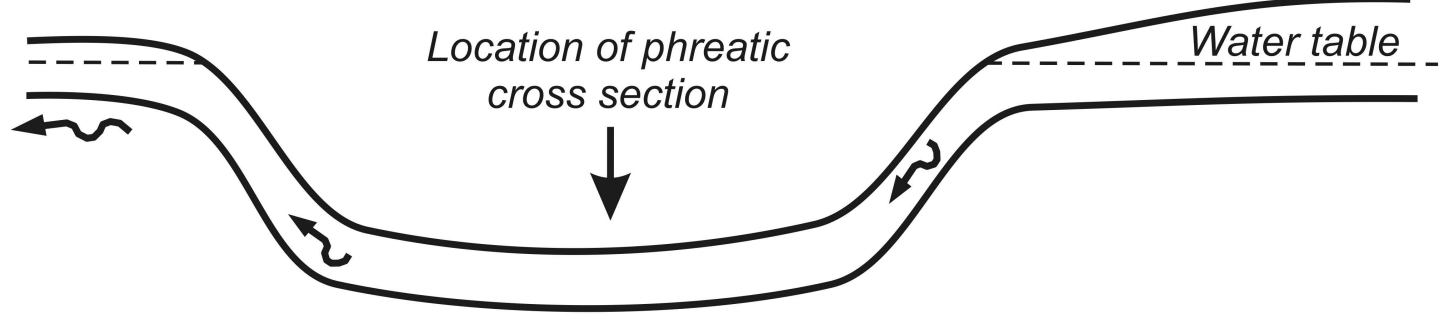

\section{$t=2$ Sediment influx and paragenesis}

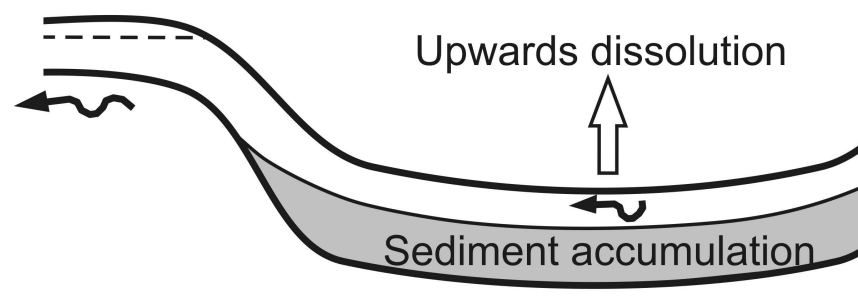

Location of vadose cross section
Phreatic Cross

Section
Vadose Cross Section



Vadose trench

Phreatic tube

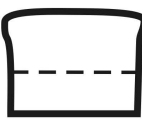

Vadose trench

\section{$t=3$ Cessation of paragenesis}



\section{$t=4$ Abandonment and vadose stripping of sediment fill}



Lateral incision and notch formation

Paragentic half

Flat roof



\section{tube and pendants}

OR



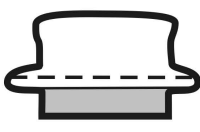

Formation of alluvial notch
Clay

(cap muds)

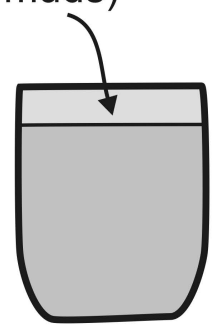

After complete blockage and drainage

Speleothem

OR<smiles>C1CCCCC1</smiles>

Aft



After vadose incision and sediment removal 


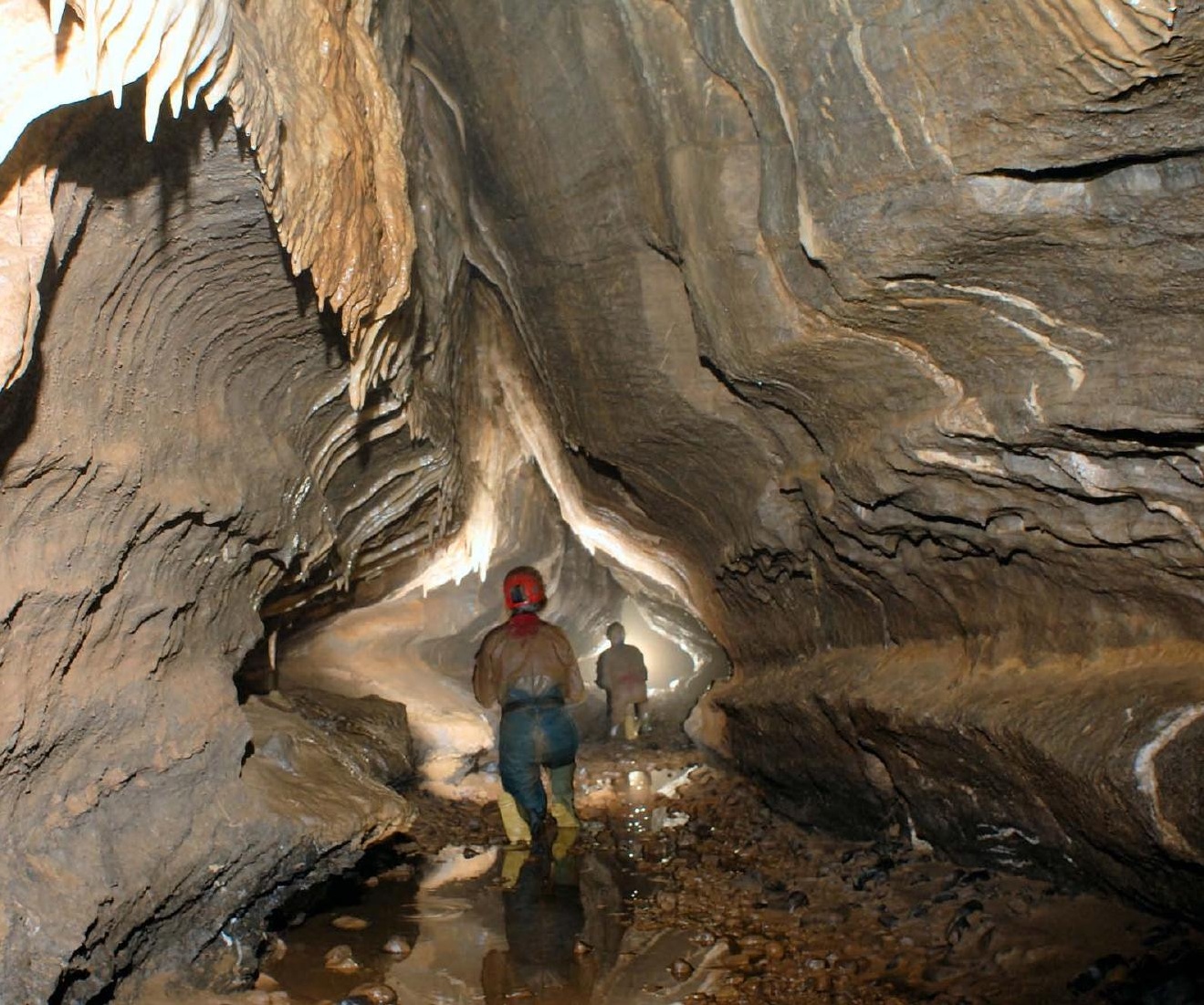




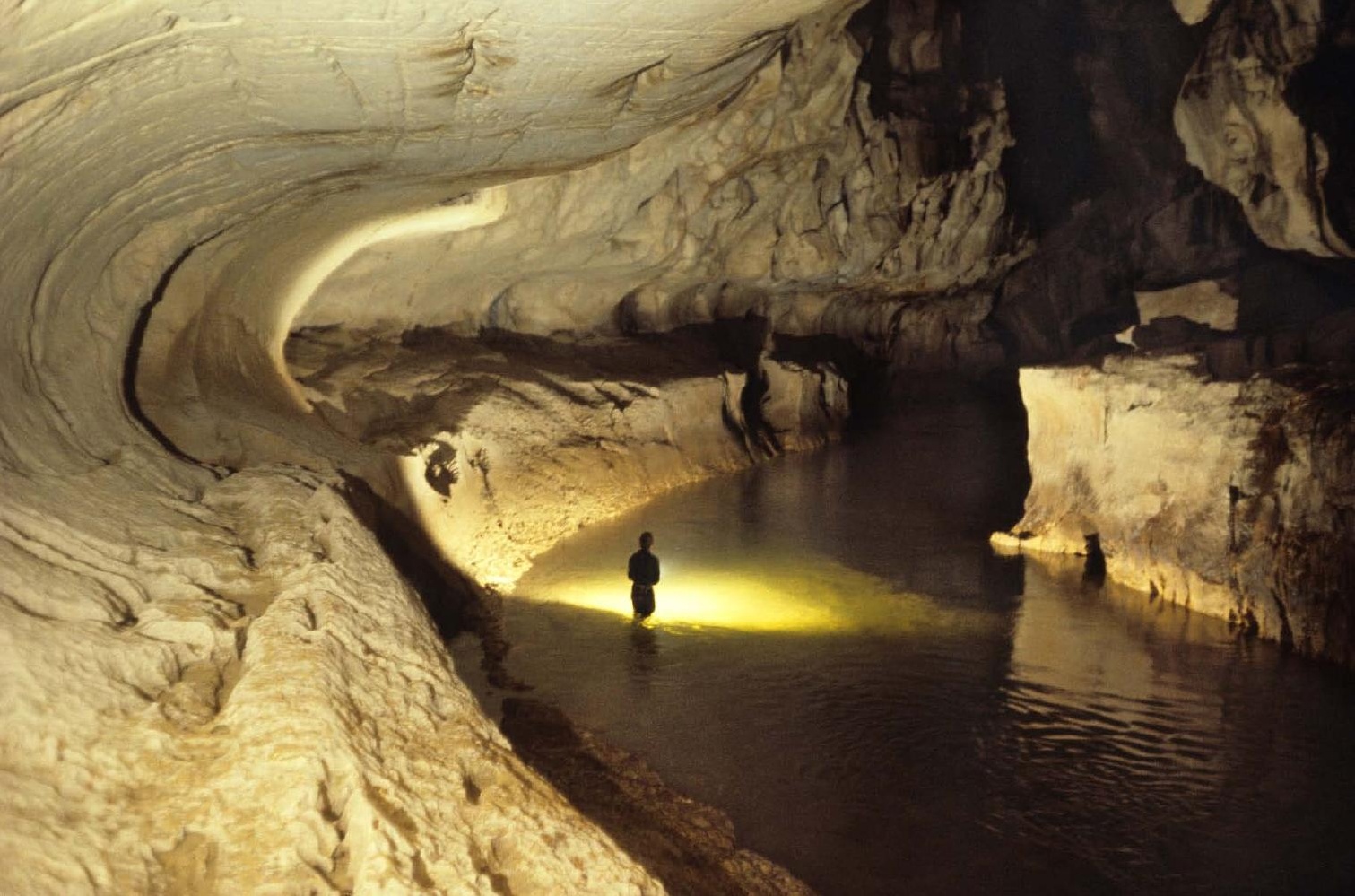




\section{A. Armistice Passage plan view.}

High sediment flux: Vadose alluviation and notch formation without phreatic undercapture

Cross section A



B. Cairn Farm plan view.

Without sediment input: Braided phreatic looping

Cross section B passages developed along bedding plane.

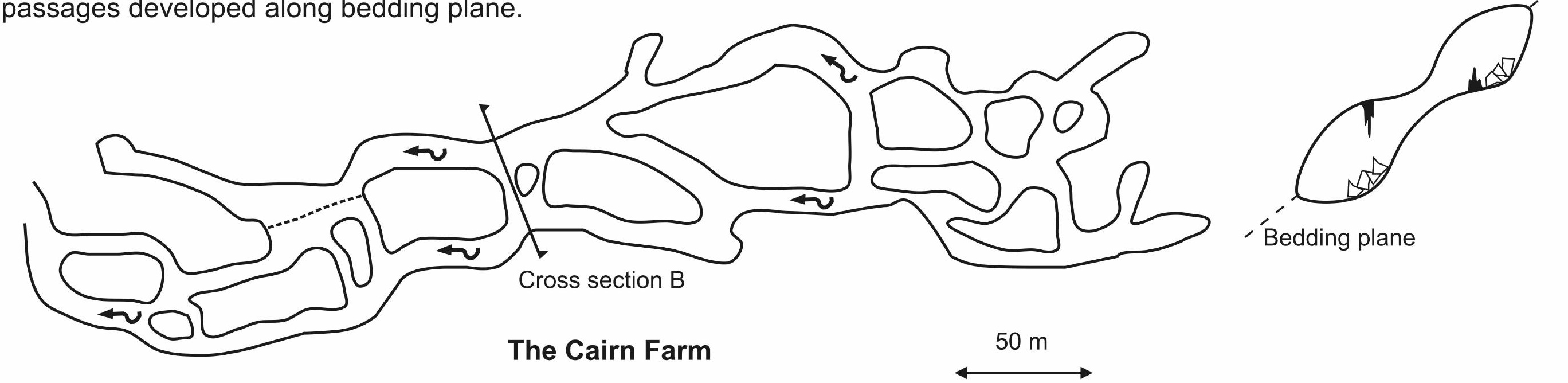




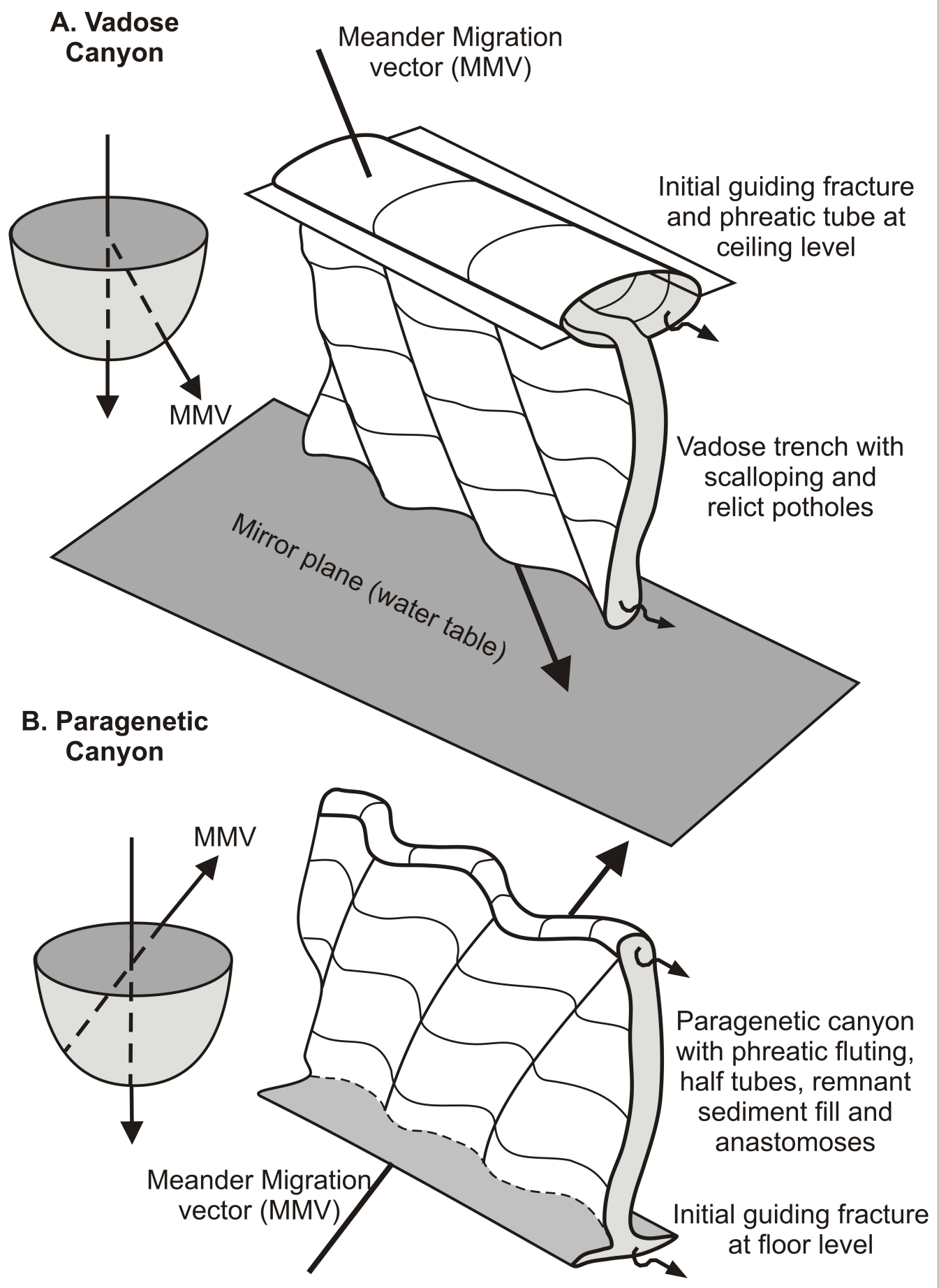




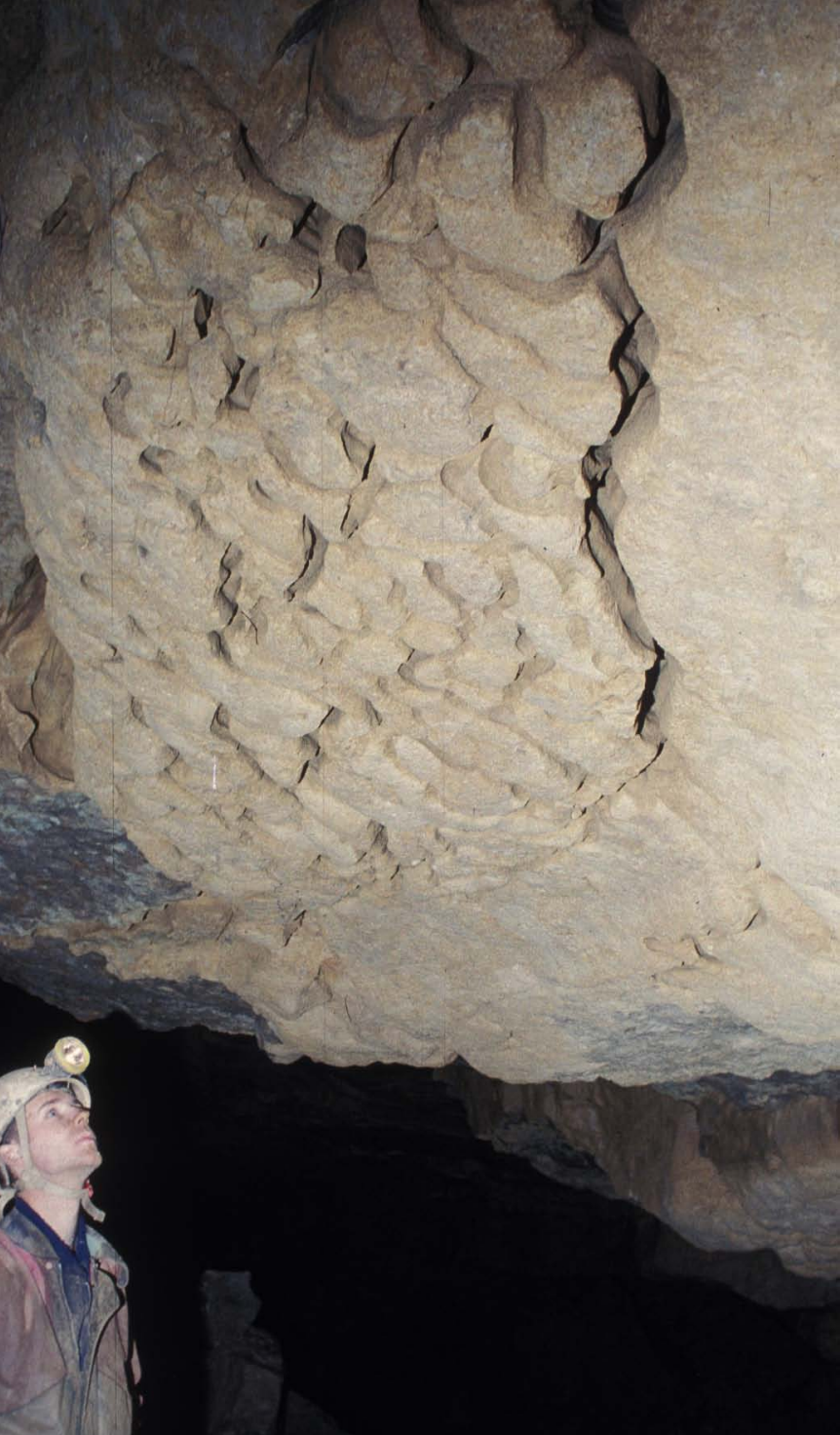




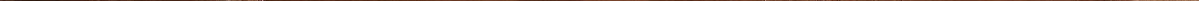




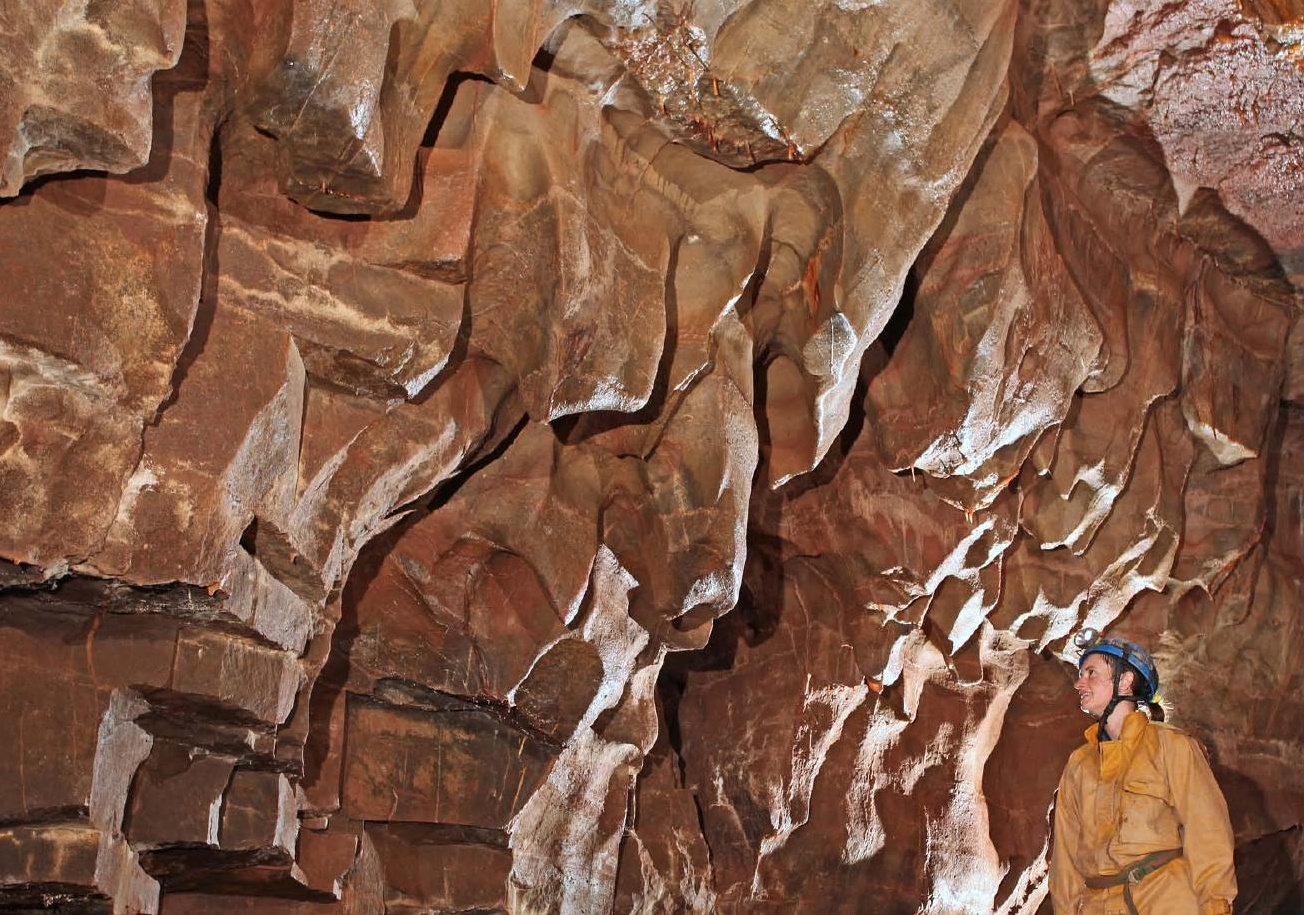




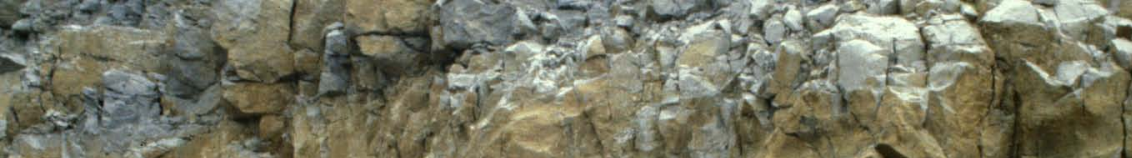



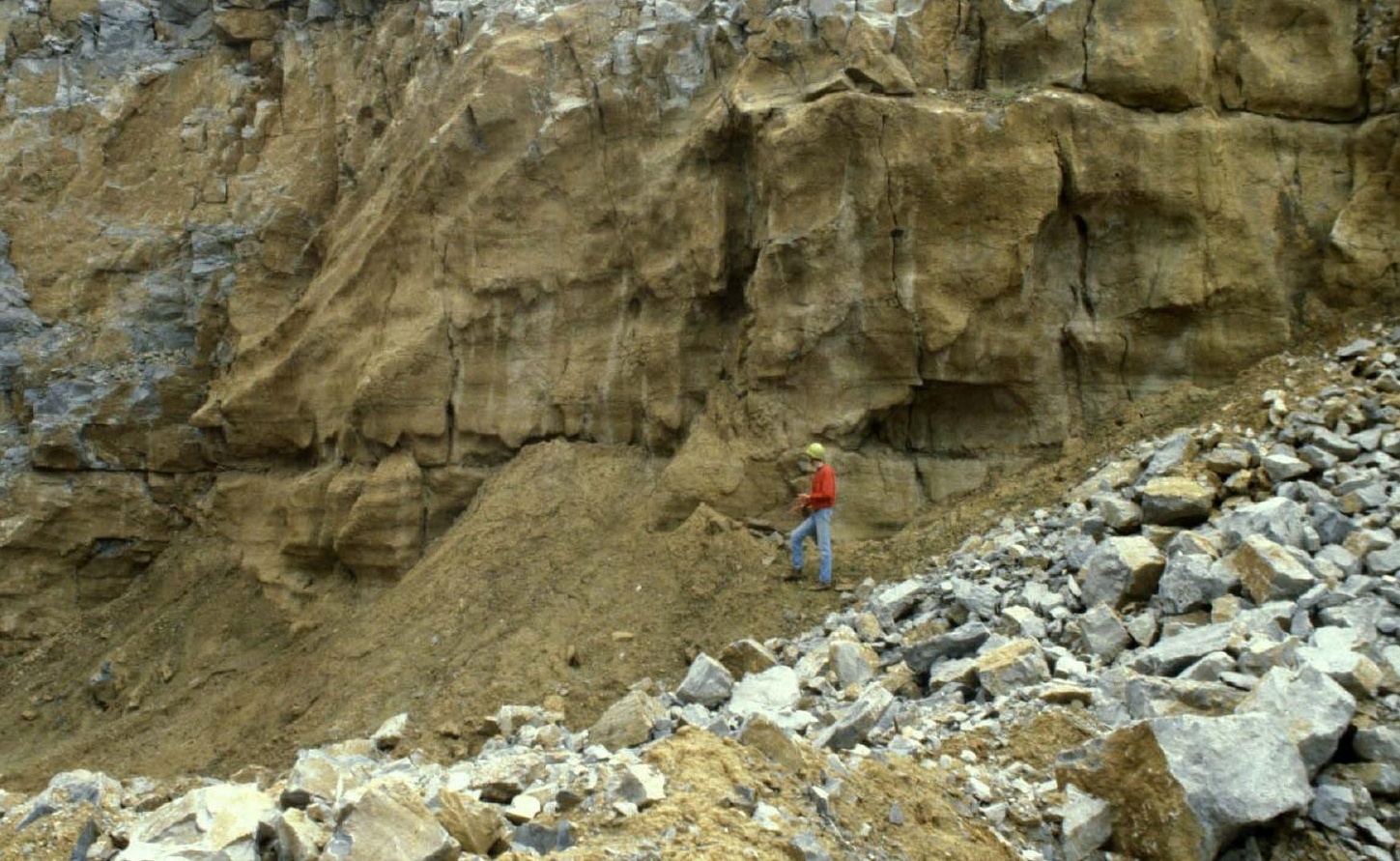




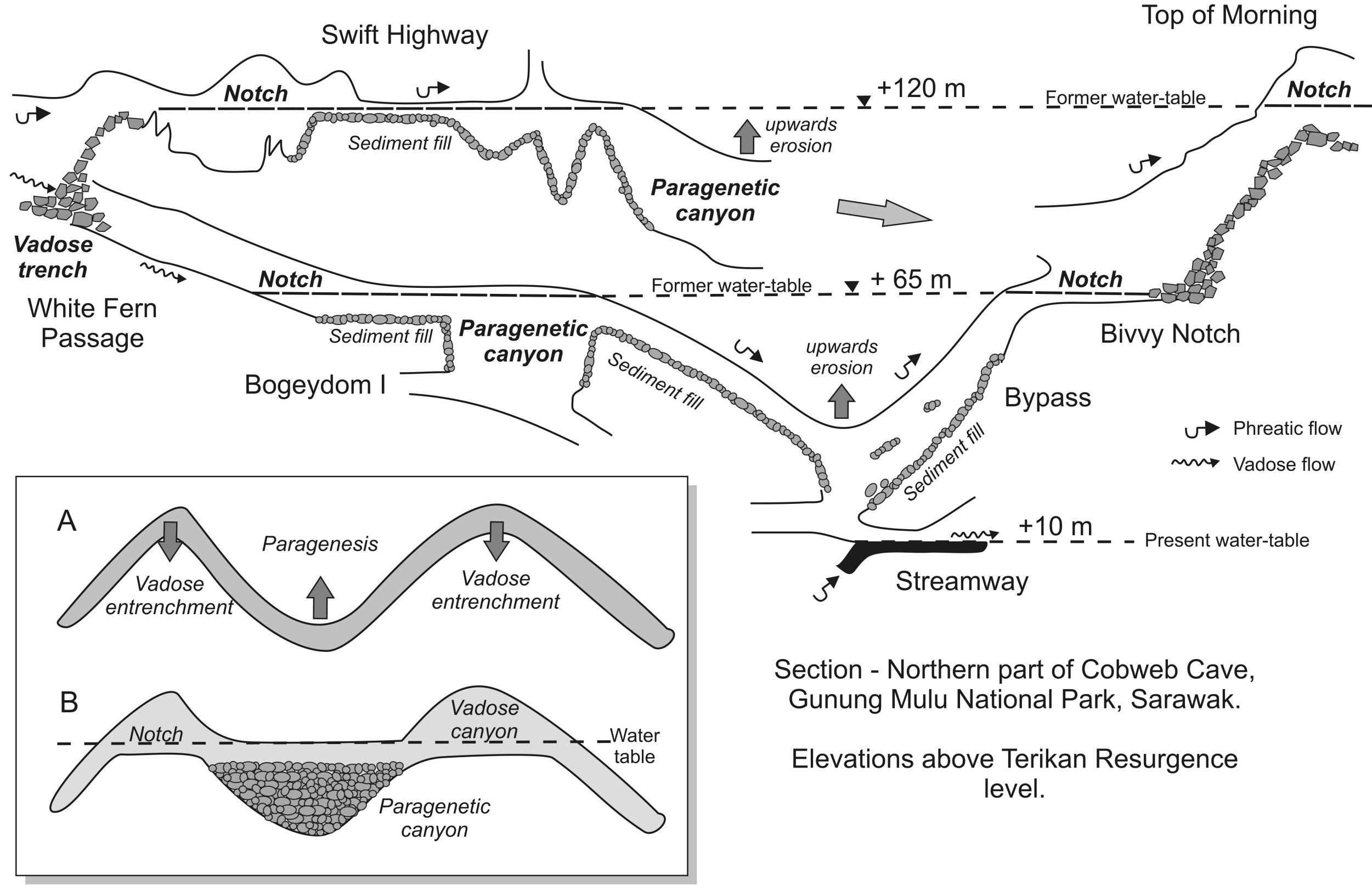




\section{Figures and Tables}

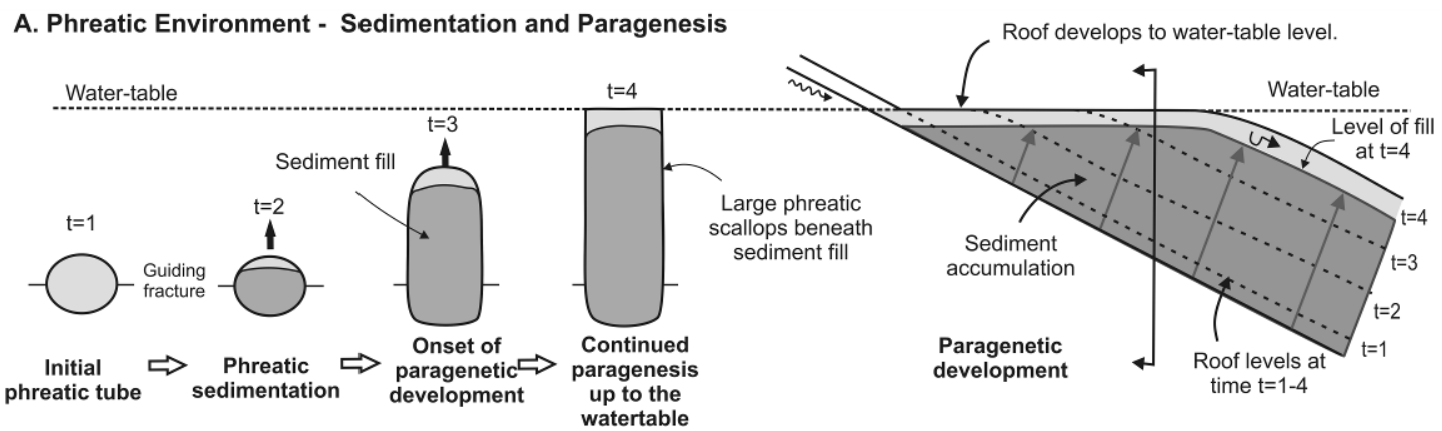

B. Vadose Environment - Incision followed by alluviation

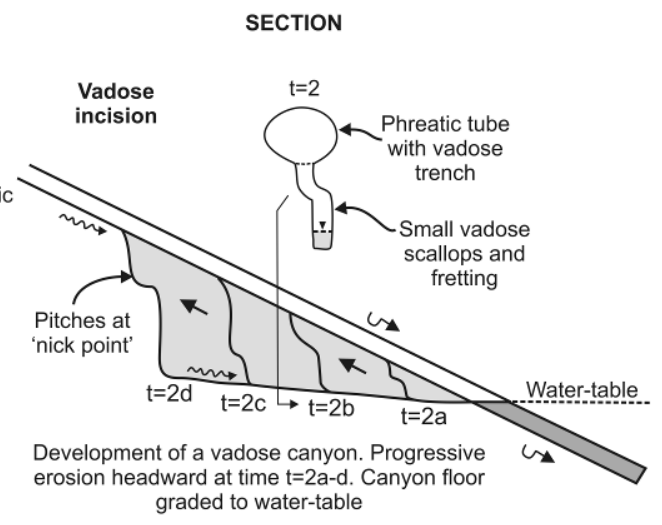

Figure 1. Schematic evolution of a conduit showing effect of sediment influx into vadose and phreatic environments. In phreatic conduits (A), sedimentation will result in the upwards dissolution of a conduit by paragenesis, creating a sediment filled gallery. This may occur over several phases of sediment input and upwards dissolution. In a vadose environment (B), the initial phreatic tube will be incised by one or more phases of vadose incison, creating a classic keyhole passage cross section (shown at $\mathrm{t}=2$ and in the section). Subsequent alluviation by sediment may infill an existing vadose passage, leading to paragenetic-type overprinting of existing vadose morphologies. This may be associated with one or more phases of sedimentation and flushing. If sedimentation continues unchecked, it may lead to full paragenesis in a phreatic environment, with the development of paragenetic rifts incised upwards into the roof of the existing phreatic tube. Each of the individual phreatic, vadose and paragenetic components at $\mathrm{t}=4$ may be formed at different times under different discharge regimes, and thus may not be equal in size. 


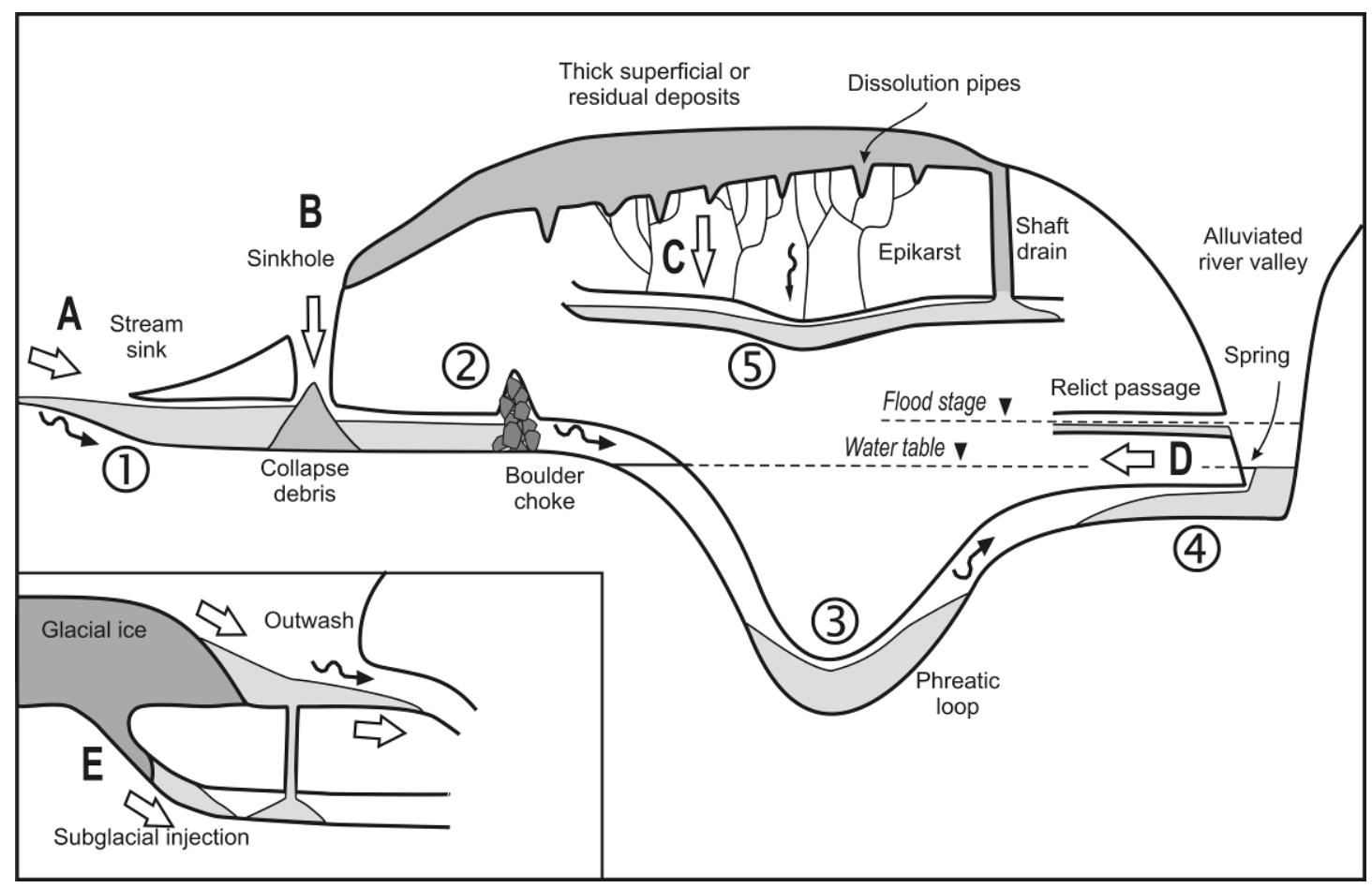

Figure 2. Schematic cross-section of a cave system showing major sediment influx routes and accumulation points. Sediment entry points: A. via stream sinks. B. Through sinkhole collapse and surface runoff via open sinkholes (collapse debris is shown as darker grey). C. Via fissure networks within the epikarst, dissolution pipes and shaft drains. D. Back-flooding from adjacent river systems, both via springs and relict passages during flood events, especially in areas with rising base-level. E. Glacial injection, either by direct sub-glacial injection of glacial till or from glaciofluvial outwash.

Preferred areas of sediment accumulation: 1 . Near-surface passages close to sediment input points, especially low gradient river passages or constricted entrance passages. 2. Behind boulder collapses, or other restrictions such as sinkhole collapses. 3. Within phreatic loops, or in flooded sections of cave passage with standing water. 4. In active and relict passages subject to back-flooding from rivers. 5. In relict passages subject to infilling from shaft drains and fissures. 




Figure 3. Schematic cartoon of a vadose stream cave with relict tributary and network maze passages showing the classification of clastic cave sediment facies of Bosch and White, 2007. 


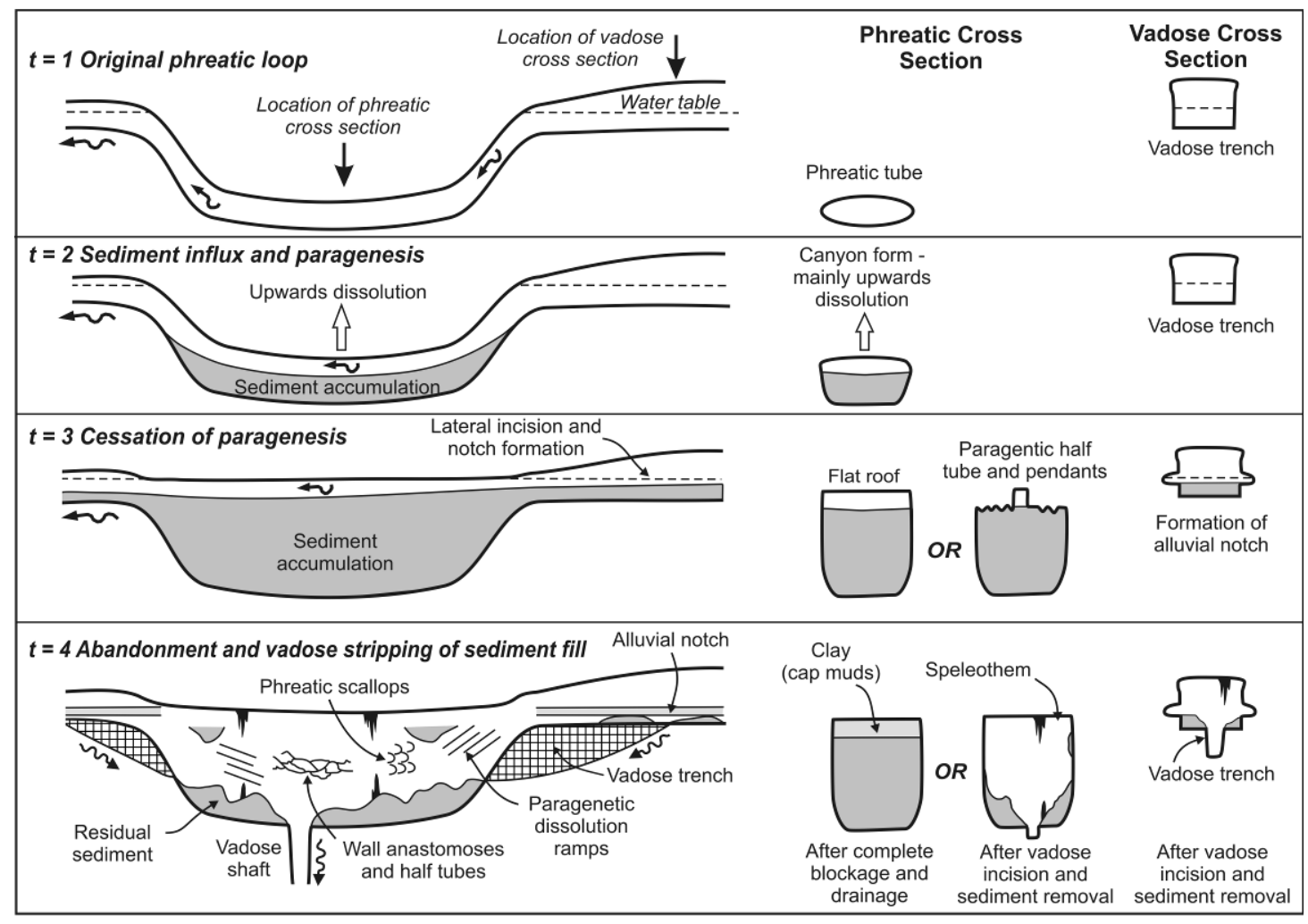

Figure 4. Evolution of paragenetic galleries and alluvial notches in phreatic and vadose situations (elevation and cross sections) under conditions of high sediment flux and following abandonment. 


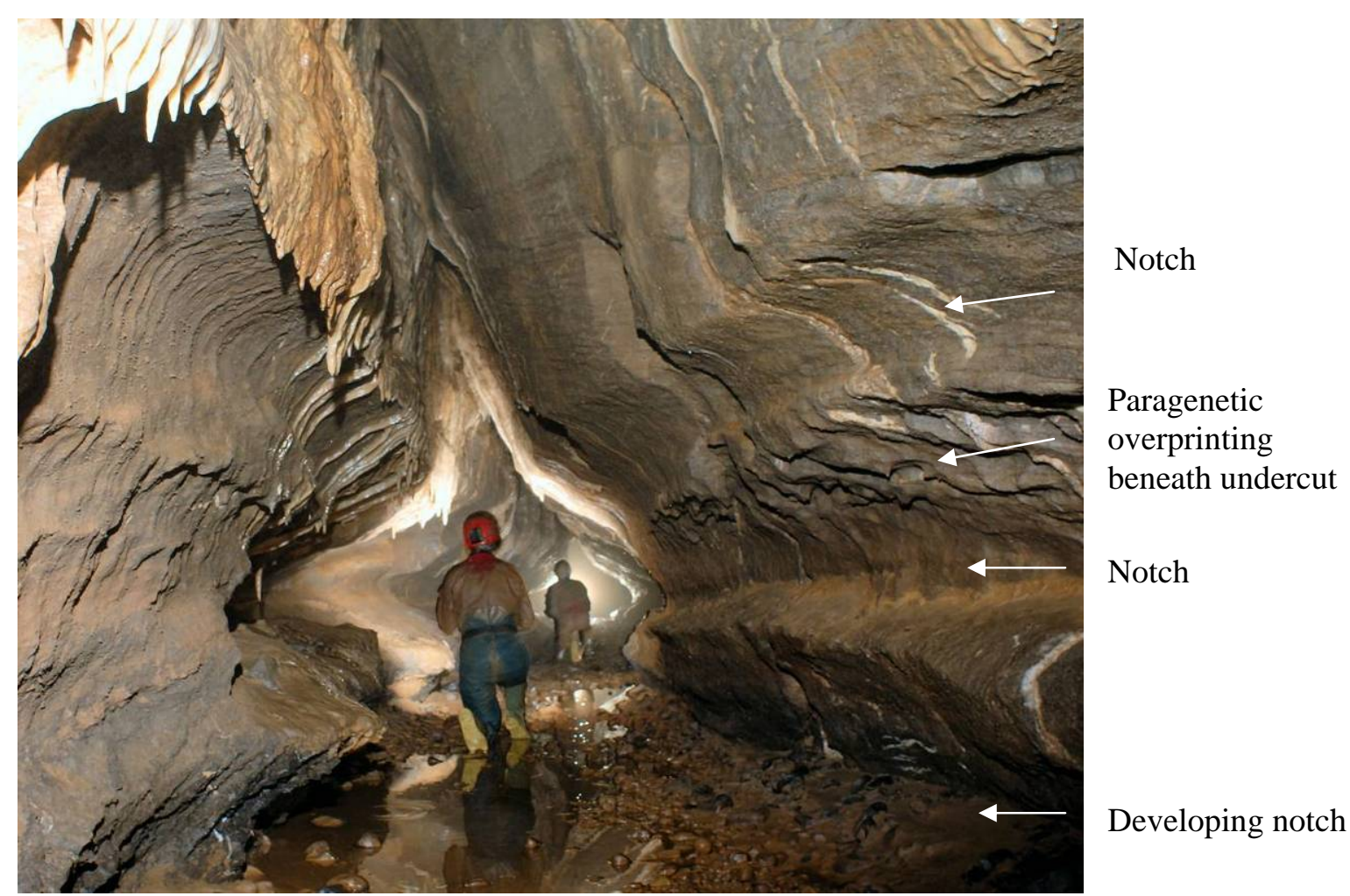

Fig $5 \mathrm{~A}$

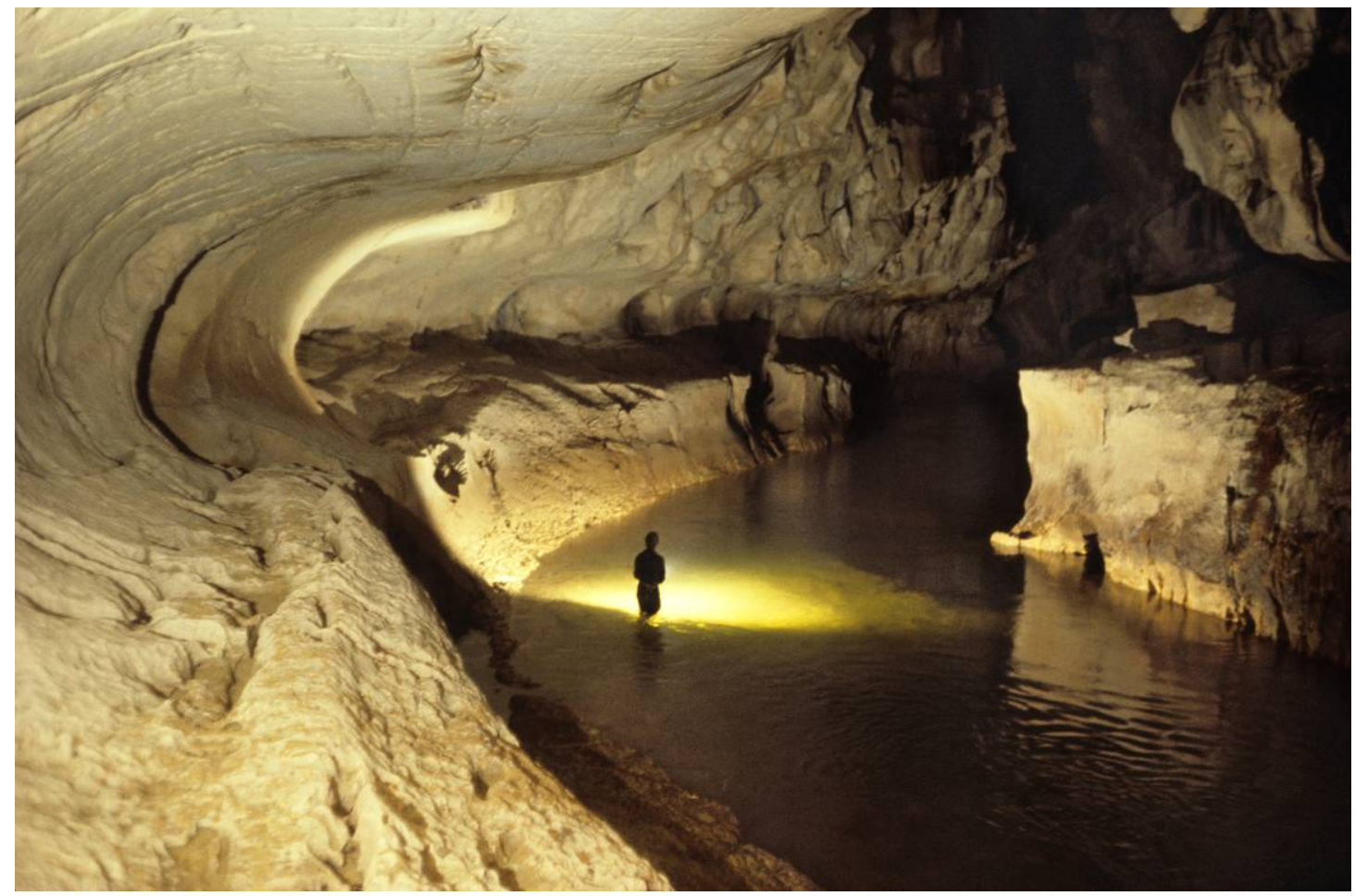

Fig 5B

Figure 5. Vadose alluvial notches. A) Coarse sandstone-rich sediment washed into this jointguided vadose passage has formed two notches visible on the walls, and a third is currently developing at floor level. Paragenetic overprinting of vadose wall morphologies have created 
the anastomoses, pendants and half tubes developed on the undercut below the upper notch. This passage is approximately $1 \mathrm{~km}$ from, and $200 \mathrm{~m}$ below the sink. Route 66, Charterhouse Cave, Somerset, UK. Photo by Peter Hann.

B). Large scale vadose alluvial notches developed by fluvial aggradation in a humid tropical environment. The notches developed during periods when the Melinau River was routed through the cave during periods of active alluvial fan aggradation. The present river is not fed by major allogenic sources and is no longer aggrading its bed. Clearwater Cave, Gunung Mulu, Sarawak. Photo by Tony Waltham Geophotos. 

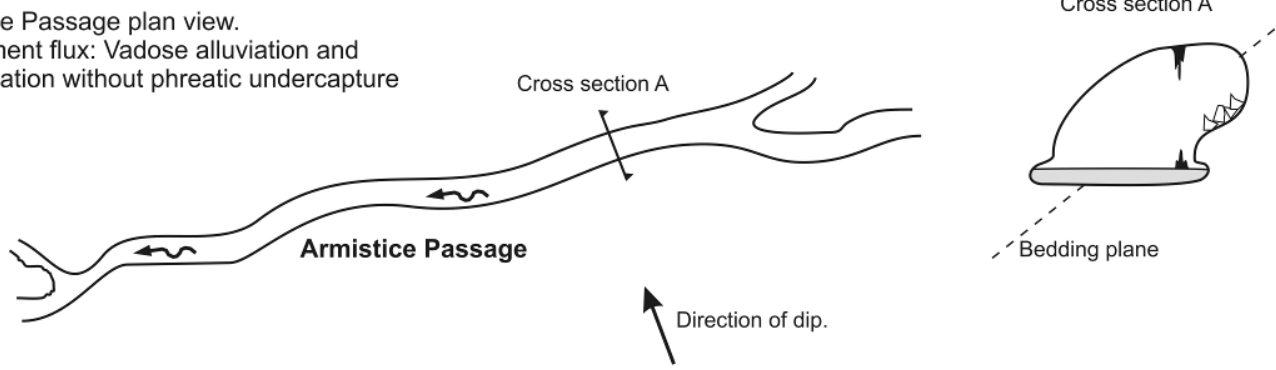

B. Cairn Farm plan view.

Without sediment input: Braided phreatic looping

passages developed along bedding plane.

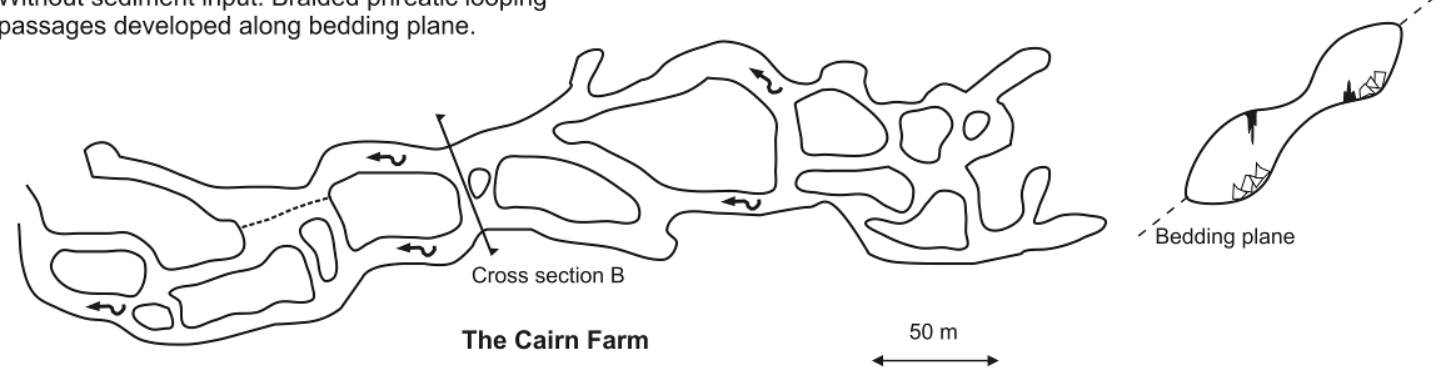

Figure 6. Plan view and cross sections through the Armistice and Cairn Farm passages in the upper part of Clearwater Cave, Mulu, Sarawak. Armistice Passage has an allogenic sediment fill which has prevented down-dip phreatic under-capture. In contrast, the Cairn Farm series of passages (which underlies Armistice) does not have a significant fill and consequently has developed an anastomotic phreatic looping profile along the strike of the guiding bedding plane. 


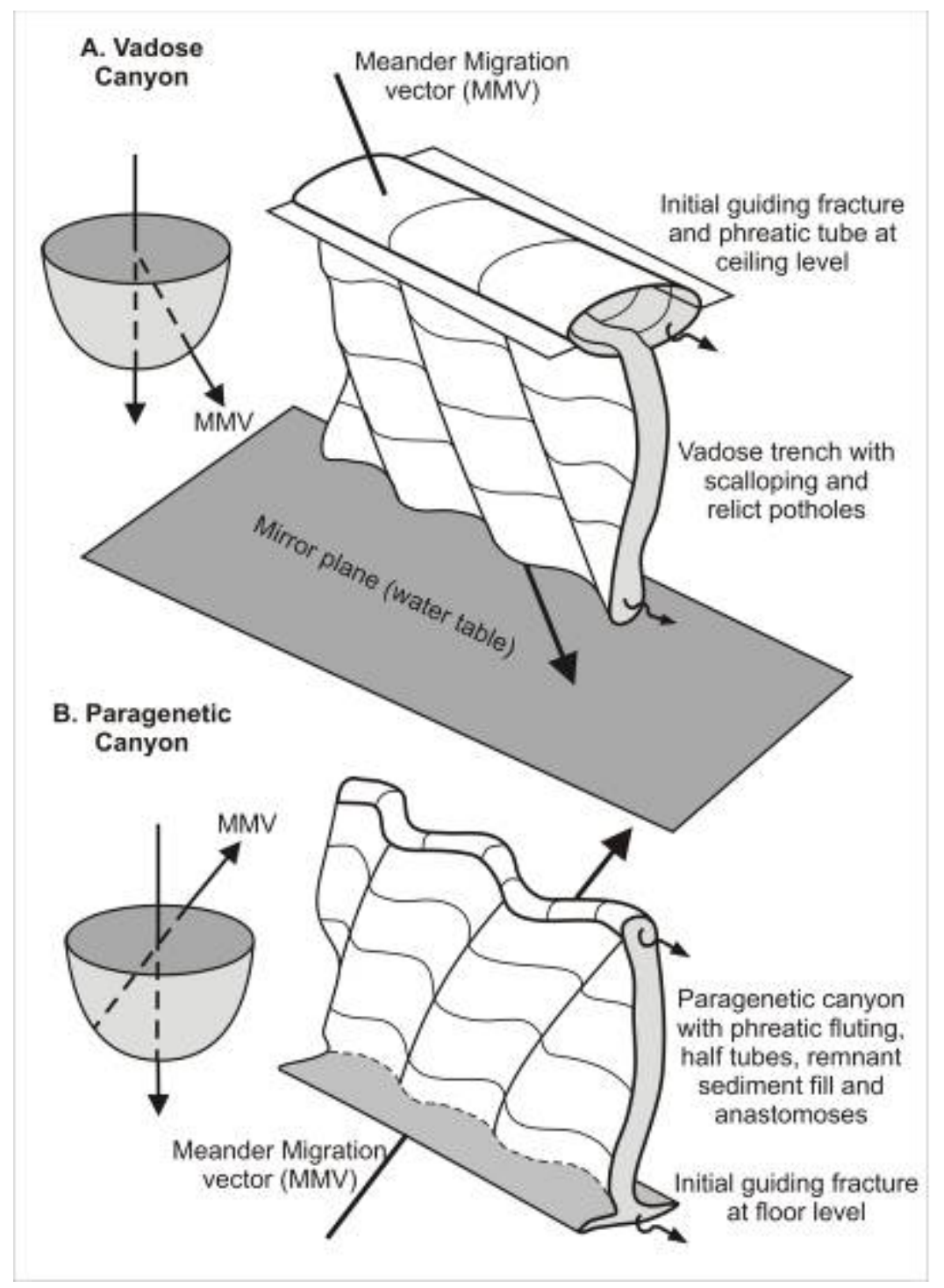

Figure 7. Differential diagnosis between vadose canyons and paragenetic (antigravitative) canyons. Vadose canyons form above the water-table whilst paragenetic canyons form below it, thus forming a mirror pair. The meander migration vector (MMV) is determined from scalloping and canyon walls, and can be plotted on the upper and lower hemispheres of a stereonet. Figure from Lauritzen and Lauritsen, (1995). 


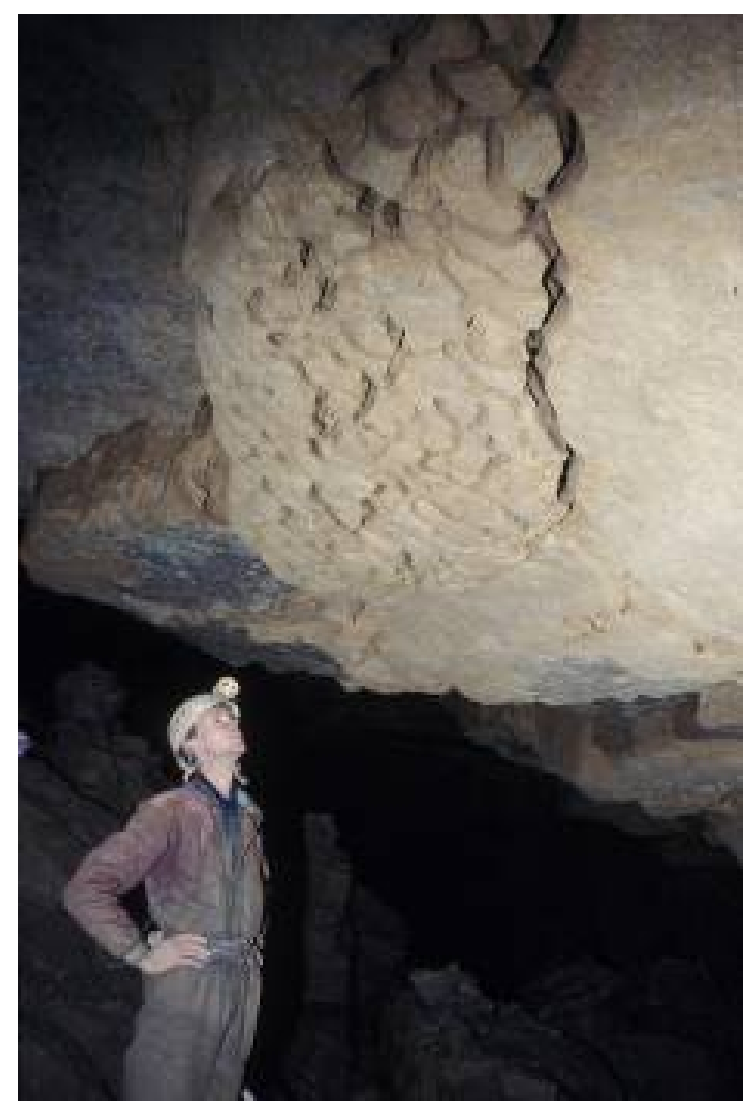

Fig. 8A.

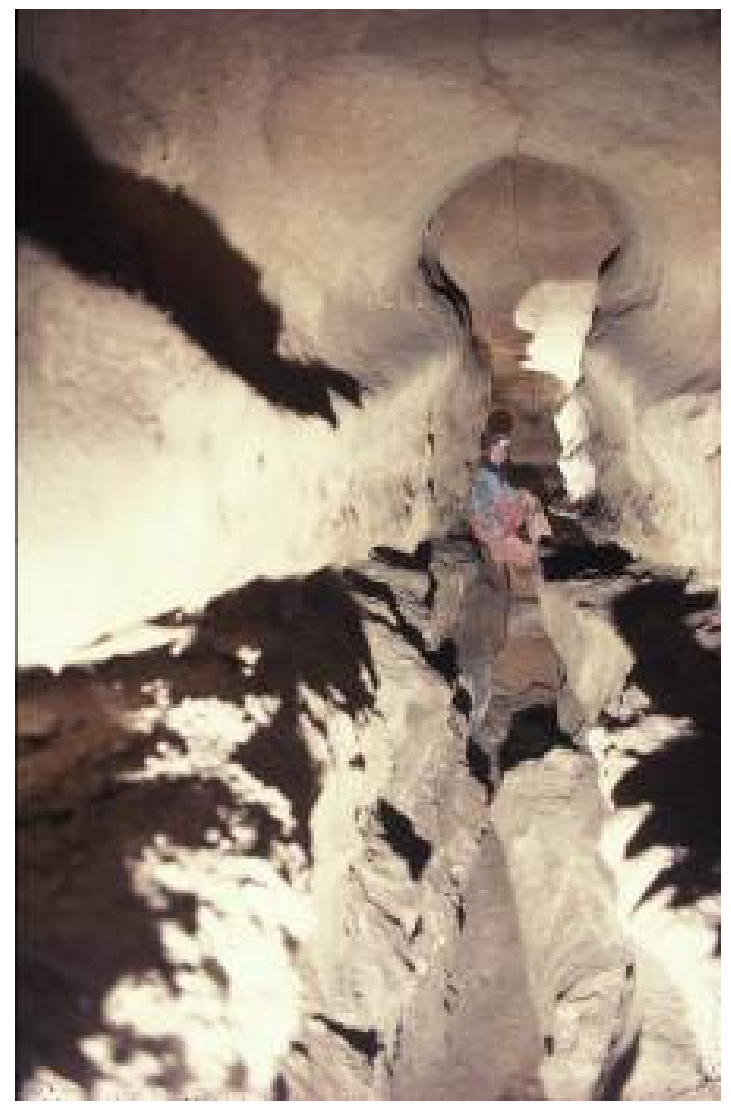

Fig. 8B. 


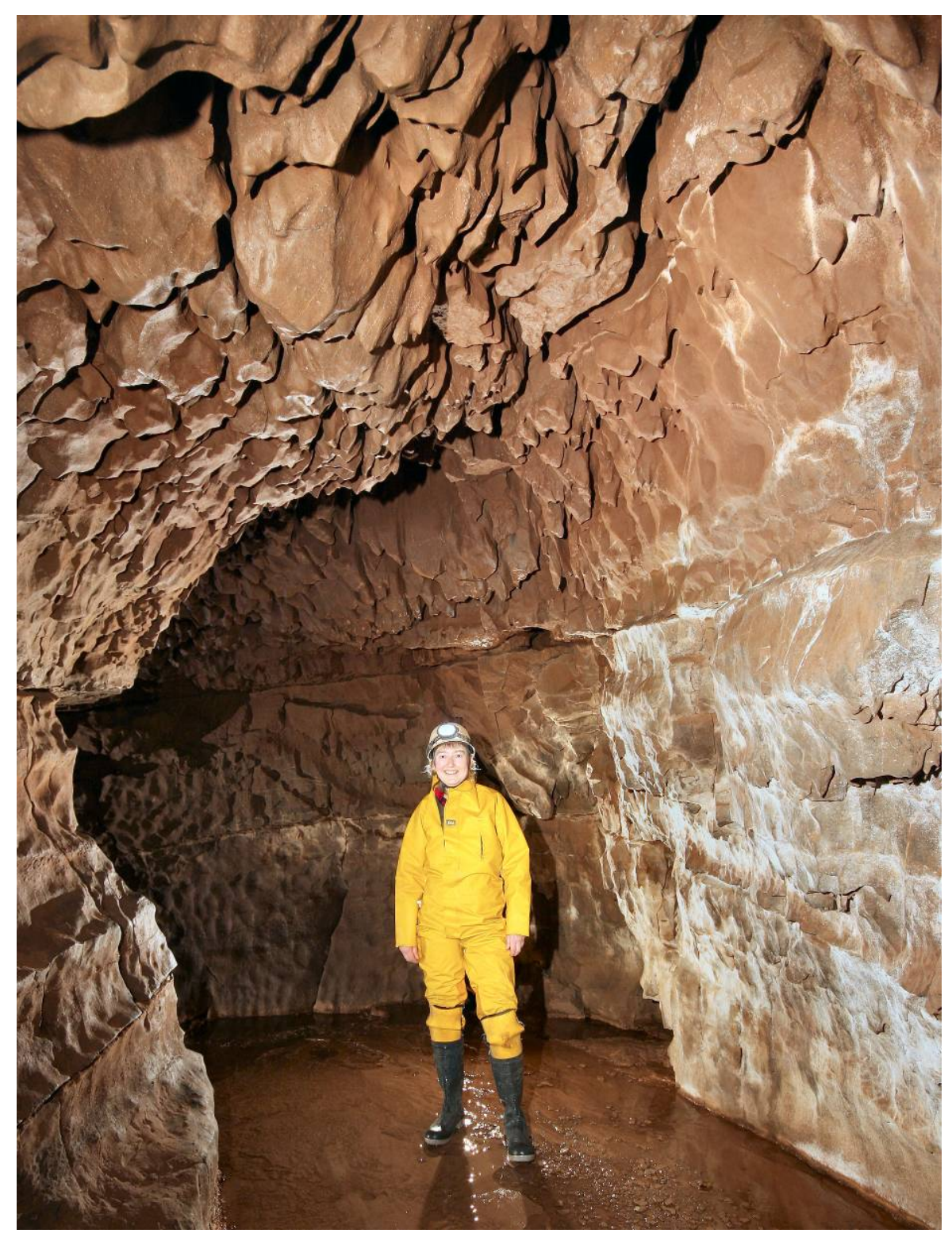

Fig. 8C. 


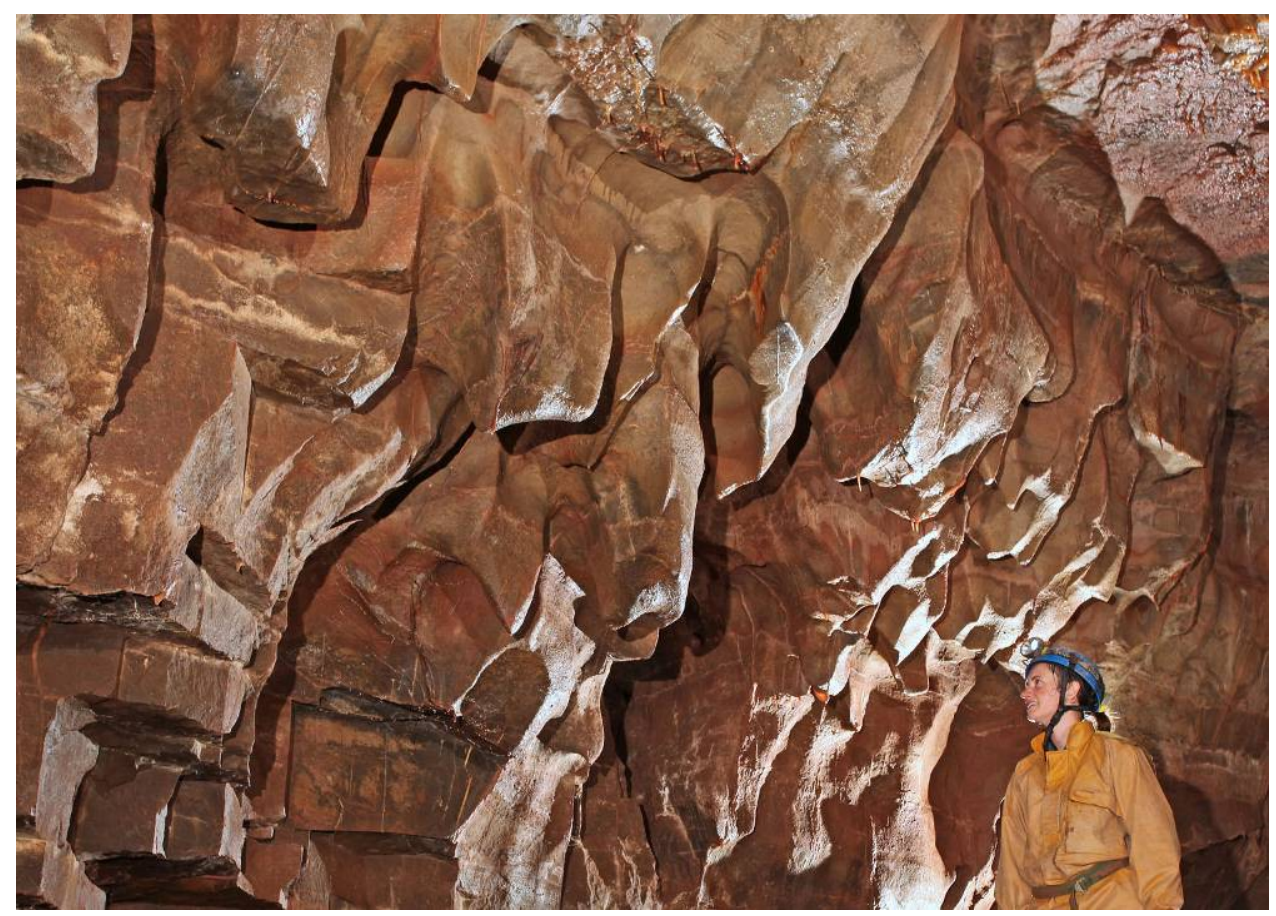

Fig. 8D.

Photomontage of characteristic meso and micro dissolutional features associated with paragenesis.

8a. Anastomotic half tubes etched into the underside of an overhang following vadose alluviation, Padlock Passage, Ogof Draenen, South Wales, UK. Photo by M J Simms.

8b. Paragenetic roof tube and vadose canyon. This passage, developed along a prominent joint displays phreatic, paragenetic and vadose features. The uppermost part of the passage is a well developed rounded phreatic tube (developed above the sediment fill) beneath which is a narrower paragenetic gallery, but with characteristic smooth rounded forms typical of a phreatic environment. The sediment was subsequently flushed out and a vadose trench incised into the floor (below the figure). Raider's Passage, Ogof Draenen, South Wales, UK. Photo by M J Simms.

8c. Paragenetic anastomoses, pendants and half tubes in a paragenetic passage. Columns Passage, Ogof Ffynnon Ddu I, South Wales, UK. Photo by B. Marris.

8d. Anastomotic paragenetic half tubes on passage walls with intervening pendants in a phreatic passage infilled by glacially derived sediment. Entrance Passage, Ogof Ffynnon Ddu II (Top Entrance), South Wales, UK. Photo by B. Marris. 


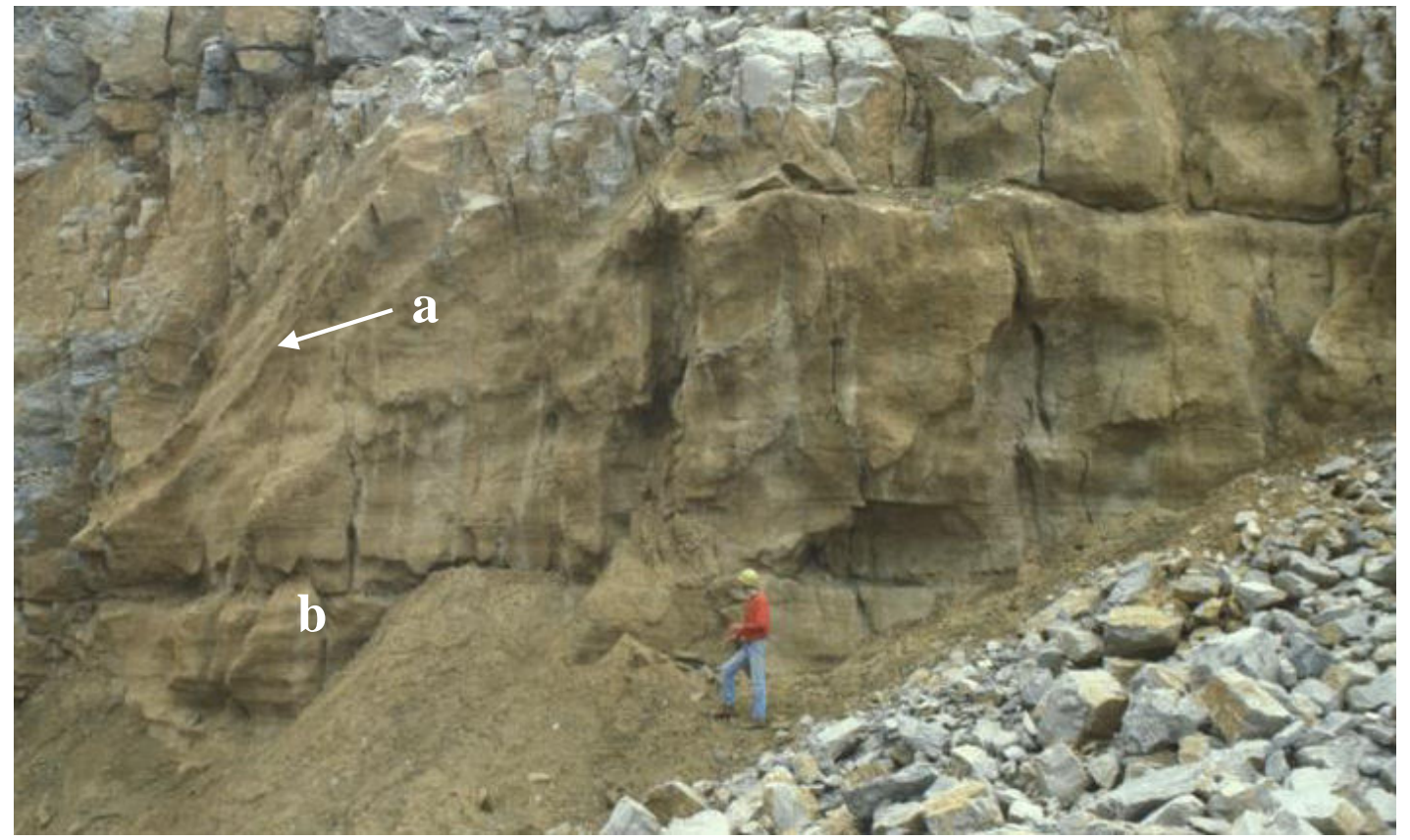

Figure 9. Section through a paragenetic passage exposed by quarrying, Eldon Hill Quarry, Derbyshire, UK. This is a longitudinal section, where one wall of a sediment filled passage has been removed by quarrying allowing sight of the other wall. The former passage is marked by brown mud-stained dissolutionally etched limestone. Above and to the left of the figure are several conspicuous paragenetic dissolution ramps (a) dipping steeply down to the quarry floor on the left of the image. The prominent bedding plane at head height has been picked out by dissolution and displays several examples of paragenetic pendants (b).

Remnants of the sediment fill form the scree slopes upon which the figure (approximately 1.9 $\mathrm{m}$ tall) is standing. The passage exits the quarry through a small $1 \mathrm{~m}$ diameter tube to the left of the image. Photo by M J Simms. Similar paragenetic dissolution ramps are shown in Palmer (2007), p. 154. 


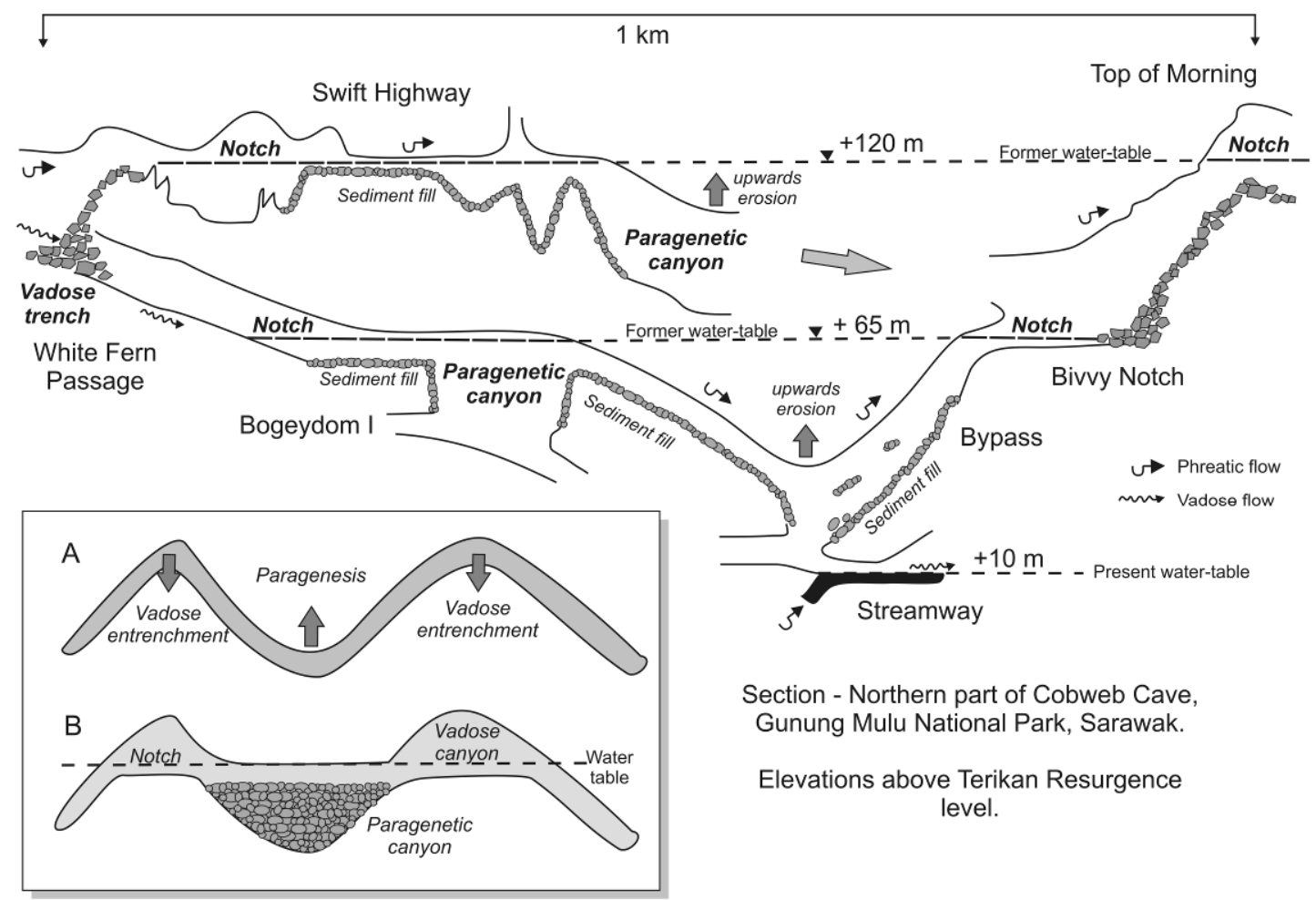

Figure 10. Example of sequential paragenetic development and vadose notch formation from Cobweb Cave, Gunung Mulu National Park, Sarawak. Notch development initially graded to a water-table at $120 \mathrm{~m}$ followed by a fall to $65 \mathrm{~m}$. Much of the sediment fill has been eroded by later vadose invasion stream activity. Inset: Paragenetic influences on passage long section. Vadose incision over loop crests and paragenetic upwards erosion in phreatic loops (A) combine to create a graded water-table cave (B). 


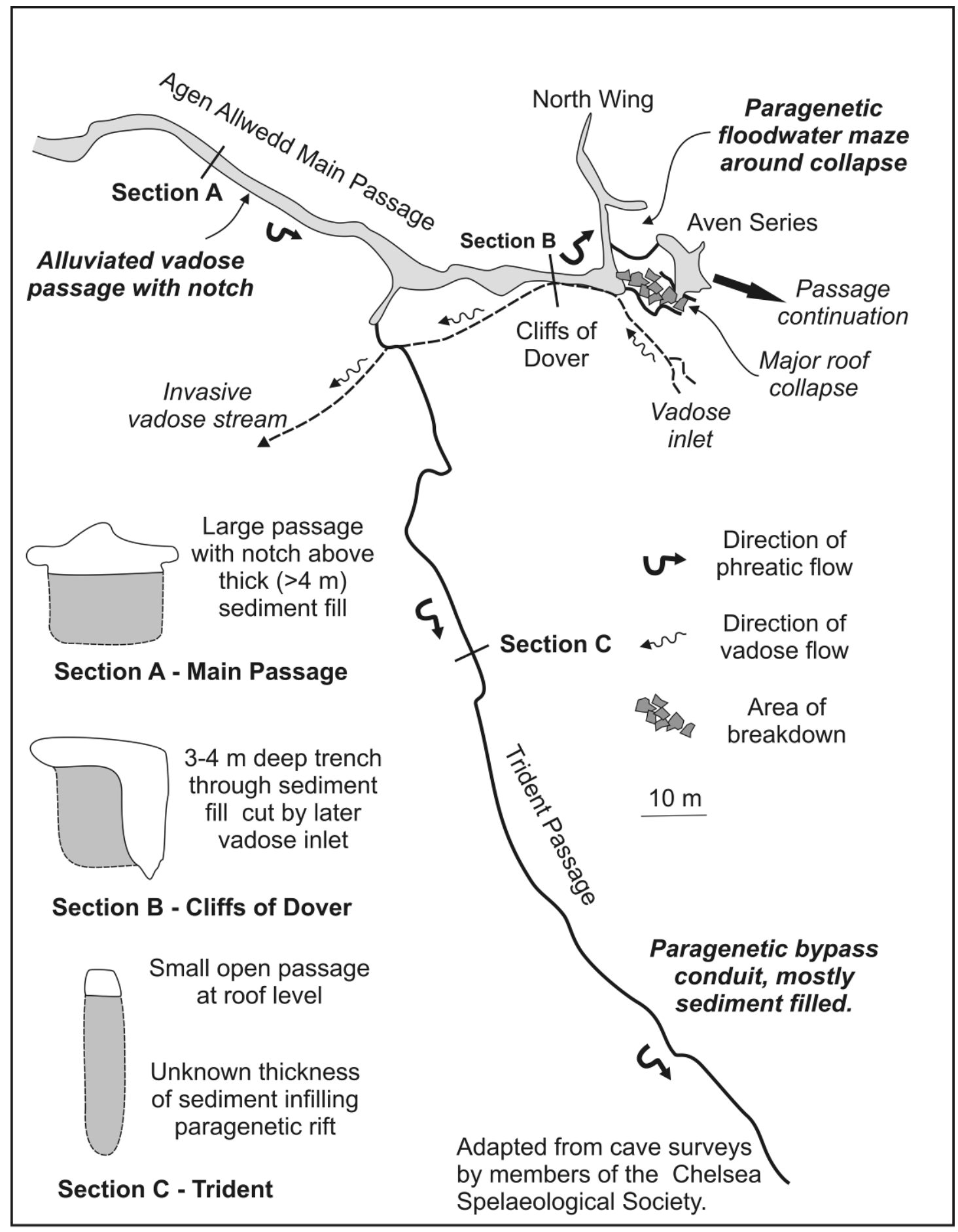

Figure 11. Plan view of the eastern end of the Main Passage in Agen Allwedd, Mynydd Llangattock, South Wales, UK. Collapse has led to the development of a paragenetic floodwater maze around the terminal choke (North Wing and Aven Series), and caused the development of a paragenetic bypass passage developed along joints to the southeast (Trident Passage). 


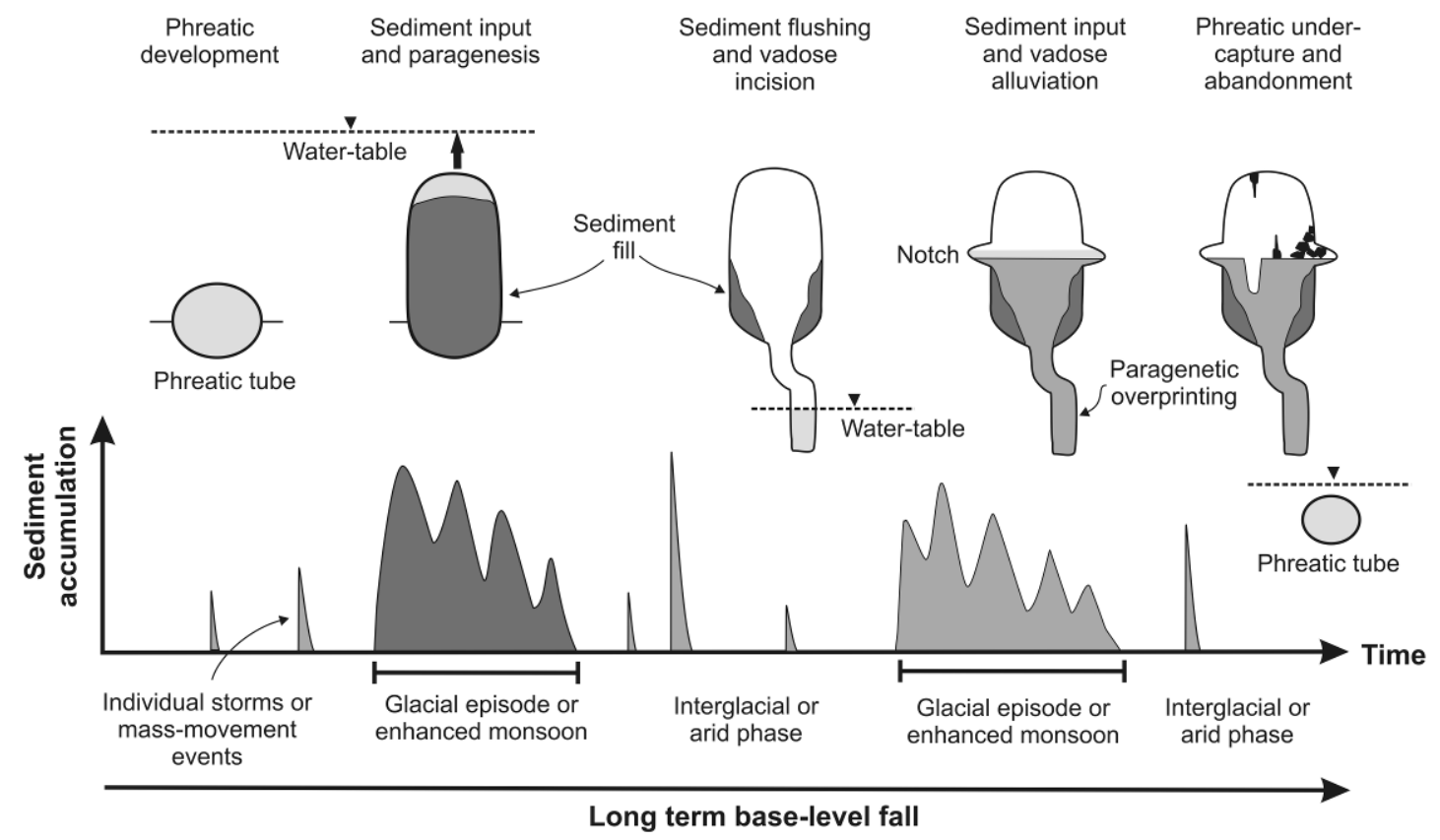

Figure 12. Schematic lifecycle of a cave over time. In this example, multiple phases of sediment accumulation and flushing have occurred over a range of timescales in response to external forcing. This may be due to short term events such as individual storms or mass movement events, or to longer term climatic changes such as a change to a glacial or periglacial regime or fluctuations in monsoonal rainfall. Initially, phreatic dissolution with coeval sediment aggradation led to upwards paragenesis. Subsequent base level fall caused a period of vadose incision, only for a second phase of sediment accumulation to bury the passage, overprinting existing vadose morphologies. Ultimately, abandonment, often preceded by at least partial sediment flushing and vadose rejuvenation, is the almost inevitable consequence of longer term uplift and or base-level fall. In some caves, the amount of sediment input and residence time may be negligible, in others large amounts of sediment may reside in the cave for much of its lifespan. 